\title{
Does Board Independence Reduce the Cost of Debt?*
}

\author{
Michael Bradley ${ }^{1}$ and Dong Chen ${ }^{2}$
}

\begin{abstract}
Using the passage of the Sarbanes-Oxley Act and the associated change in listing standards as a natural experiment, we find that while board independence decreases the cost of debt when credit conditions are strong or leverage low, it increases the cost of debt when credit conditions are poor or leverage high. We also document that independent directors set corporate policies that increase firm risk. These results suggest that, acting in the interest of shareholders, independent directors are increasingly costly to bondholders with the intensification of the agency conflict between these two stakeholders.
\end{abstract}

February 4, 2014

JEL Classification: G34, K22

Keywords: corporate governance, Sarbanes-Oxley Act, board independence, risk-taking, credit condition, leverage, bondholder/shareholder conflict, cost of debt, propensity score

\footnotetext{
${ }^{*}$ This is a substantially revised version of the paper circulated earlier under the title "Corporate Governance, Credit Condition, and the Cost of Debt". We thank an anonymous referee for very helpful comments, and Yanyan Liu.

${ }^{1}$ Duke University, 100 Fuqua Dr, Durham, NC, 27708. bradley@duke.edu, (919)660-8006, (919)660-7971(fax)

${ }^{2}$ University of Baltimore, 1420 N Charles St, Baltimore, MD 21201. dchen@ubalt.edu, (410)837-4919, (410)837$5722($ fax)
} 


\section{Introduction}

Prior literature suggests that independent directors generally perform a better monitoring role than affiliated or inside directors regarding shareholder welfare (see, e.g., Fields and Keys, 2003; Hermalin and Weisbach, 2003). This is consistent with the reputational concerns of these directors as professional referees (Fama, 1980). Because some monitoring functions such as the reduction of managerial shirking or perquisite consumption, and the improvement of financial disclosure and transparency also redound to creditors' benefit (Goh et al., 2012; Armstrong et al., 2013), board independence may benefit bondholders as well. Consistent with these arguments, most studies document a negative association between independence and the cost of debt (Bhojraj and Sengupta, 2003; Anderson et al., 2004; Ertugrul and Hegde, 2008).

An average beneficial effect of board independence on the cost of debt, however, does not necessarily suggest there are no costs of independence on bondholders. It may simply suggest that overall the benefits of independence dominate its costs. Actually, the same argument that bondholders "free ride" on some monitoring benefits of independent directors for shareholders when the interests of these two stakeholders converge, also suggests that other potential actions an independent board takes may harm bondholders when the interests of the two stakeholders diverge, leading to the agency costs of debt (Jensen and Meckling, 1976; Myers, 1977).

Considering both the benefits and costs of board independence may also imply a differential impact of independence on the cost of debt. Given that the agency costs of debt are due to the conflict of interests between shareholders and bondholders (unless noted otherwise, abbreviated as the "B/S conflict" henceforth), it is expected that such costs increase with the severity of the conflict, which is commonly characterized by closeness to default or the level of financial leverage (Bodie and Taggart, 1978; John and John, 1993). Some benefits of board independence 
such as improved financial transparency may also increase with the uncertainty over a firm as a result of financial distress (Sengupta, 1998). Therefore, both the benefits and costs of independence on bondholders may change monotonically over the intensity of the $\mathrm{B} / \mathrm{S}$ conflict. If the rates of their changes differ, a differential impact of board independence on the cost of debt conditional on the $\mathrm{B} / \mathrm{S}$ conflict is expected. ${ }^{3}$ Some prior studies examine a more pronounced effect of corporate governance on the cost of debt with the deterioration of credit quality, based on the idea that the default-associated uncertainty decreases the importance of financial statements and increases the role of governance (e.g., Bhojraj and Sengupta, 2003; Klock et al., 2005). However, the consideration of both benefits and costs, and in particular their potentially different rates of changes with the intensification of the $\mathrm{B} / \mathrm{S}$ conflict, suggests that not only the magnitude, but also the direction of the effect of corporate governance on the cost of debt may change with the $\mathrm{B} / \mathrm{S}$ conflict. Therefore, an analysis of the differential impact of a governance mechanism on the cost of debt should not only supplement the analysis of its average effect as done in the literature, but may also change the conclusions drawn from it.

Using a sample of S\&P 1,500 firms between 2001 and 2005 with senior unsecured bonds outstanding, we study the differential impact of board independence on the cost of debt conditional on the expected severity of the B/S conflict. We utilize the passage of the SarbanesOxley Act of 2002 and the associated change in the listing standards instituted by the major exchanges (abbreviated collectively as SOX subsequently) as a natural experiment. Employing propensity score weighted difference-in-differences (DID) regressions (Hirano et al., 2003; Imbens and Wooldridge, 2009), we examine the effect of an exogenous increase of board

\footnotetext{
${ }^{3}$ To better understand this argument, suppose that the costs of board independence are lower than the benefits at mild degree of the $\mathrm{B} / \mathrm{S}$ conflict, but increase at a faster rate than the benefits, eventually exceeding the benefits after a certain level of the conflict. Then the impact of independence on the cost of debt should be negative if the B/S conflict is mild, but positive if it is severe.
} 
independence on the change of the cost of debt. This methodology distinguishes our study from the rest of the literature, which relies on cross-sectional identification strategies and hence is susceptible to the endogeneity concern. We also note that few financial studies in general have employed the propensity score weighted regression methodology (see Malmendier and Tate, 2009; Stuart and Yim, 2010; Yim, 2013 for some exceptions).

To identify the noncompliant (treatment) firms, we focus on the SOX requirements that the board of all listed companies be comprised of a majority of independent directors and that all the members of a firm's audit committee be independent. In contrast to most prior studies (Bhojraj and Sengupta, 2003; Anderson et al., 2004; Ertugrul and Hegde, 2008), we do not find an overall significant effect of board independence on the cost of debt, suggesting a balance of the benefits and costs of independent directors on bondholders. However, consistent with a differential impact of board independence on the cost of debt, we find that higher independence results in a significantly lower cost of debt when the expected $\mathrm{B} / \mathrm{S}$ conflict is mild, but a significantly higher cost of debt when the conflict is severe.

In order to buttress the assertion that independent directors act in the interest of shareholders rather than bondholders, we examine the effects of board independence on the firm's subsequent risk profile and payout policies - two corporate actions that may benefit one stakeholder but hurt the other. Consistent with this view, we document that an exogenous increase in board independence leads to an increase in risk-taking behavior, which presumably benefits shareholders but hurts bondholders. However, we do not find a significant effect of independence on payout policy (dividends and repurchases).

We contribute to the literature in several dimensions. The divergent effect of board independence on the cost of debt depending on contingencies adds to the literature which argues 
that "one-size-fits-all" regulations may have unintended consequences (Chhaochharia and Grinstein, 2007; Wintoki, 2007; Linck et al., 2009; DeFond et al., 2011; Chen, 2013). Though both Chen (2013) and we analyze a differential effect of board independence on credit risk, Chen (2013) focuses on credit ratings and a non-monotonic impact, and we study bond spreads and cross-sectional variations of the impact conditional on the expected B/S conflict.

The opposite effect of board independence on the cost of debt contingent on credit condition also suggests that the common perception in the literature that governance matters more for bondholders under higher default risk may be misleading. Our results demonstrate that not only the magnitude, but also the direction of the effect of corporate governance on the cost of debt may change with a firm's credit condition.

The risk-increasing effect of board independence also adds to the related literature. In contrast to our finding, most prior studies document either a negative (e.g., Bargeron et al., 2010; Ni and Purda, 2012), or an insignificant relation between independence and risk-taking (e.g., Cheng, 2008). However, with the exception of Bargeron et al. (2010), most studies rely on crosssectional variations, which are susceptible to the endogeneity concern. ${ }^{4}$ Although a few studies employ an instrumental variable (IV) approach, there is still concern for the validity of their IVs. For example, Ni and Purda (2012) use CEO tenure as an IV for board independence. But Chen and Zheng (2013) argue and find evidence that CEO tenure matters for risk-taking behavior. It is notable that in analyzing the 2008 financial crisis, Beltratti and Stulz (2012) find that banks with

\footnotetext{
${ }^{4}$ In unreported analysis, we find some potential explanations for the difference in results between our study and Bargeron et al. (2010), though both employ SOX as a natural experiment. First, while we define 2002 as the treatment year, Bargeron et al. (2010) set 2001 as the treatment year, but still define the post SOX dummy to be one if the year is on or after 2003. This may be problematic since some noncompliant (compliant) firms at 2001 would become compliant (noncompliant) by 2002, and hence should no longer be treated as noncompliant (compliant). Second, Bargeron et al. (2010) include less control variables. Third, Bargeron et al. (2010) do not employ propensity score method to address the issue of the dissimilarity between noncompliant and compliant firms. Fourth, in Bargeron et al. (2010), standard errors are not adjusted for heteroscedasticity and autocorrelation. Finally, while we use the requirements for both the majority independence of entire boards and the full independence of audit committees to identify noncompliant firms, Bargeron et al. (2010) focus on the majority independence standard.
} 
more shareholder-friendly boards including more independent boards, are riskier. Consistent with our view, Beltratti and Stulz (2012) argue that these firms took excessive risks ex-ante in the interest of shareholders, but due to the financial crisis suffered the downside of risk-taking. The positive effect of board independence on managerial risk-taking also provides a different perspective to evaluate the effect of SOX as compared with the existing research. Most studies document that SOX discourages risk-taking (e.g., Cohen et al., 2009; Bargeron et al., 2010). Consistent with these studies, we show that risk-taking overall decreased post SOX. However, firms that were not in compliance with the independence requirement before SOX experienced a smaller decrease. Therefore, our results suggest that although many provisions in SOX, such as increased executive and director personal liabilities and the rules related to internal controls may discourage managerial risk-taking (Bargeron et al., 2010), the requirement of higher board independence nevertheless promotes risk-taking.

The remainder of the paper is organized as follows. Section 2 describes the data, variables, and summary statistics. This section also describes the timelines and provisions of SOX that are relevant for our study. Section 3 presents the empirical specifications and results. Section 4 reports the results of robustness checks on our empirical findings. Finally, Section 5 concludes.

\section{Data, SOX Provisions, Variables, and Summary Statistics}

\subsection{Data and Sample}

The Appendix provides detailed descriptions of the variables used in our empirical analysis as well as their data sources. Consequently here we provide only a brief description of each.

Following the literature, we use bond yield spread as a measure of the cost of debt. Our bond data are taken from a proprietary database from S\&P that contains the prices and issue characteristics of all publicly traded senior unsecured corporate bonds as of the end of March 
between 2002 and 2006. The year range and the inclusion of only senior unsecured bonds are a result of data limitations. But senior unsecured bonds are the most prevalent of corporate debt securities. ${ }^{5}$ To match the year convention in COMPUSTAT, the time range for the bond data is converted to be from 2001 to $2005 .{ }^{6}$ The Treasury bond data used to calculate yield spreads are from the Federal Reserve Bank Report.

Board composition data are from RiskMetrics (formerly IRRC) Director Database. The RiskMetrics database covers primarily the S\&P 1,500 firms. We obtain data from CRSP to calculate equity volatility and stock returns. Financial data are from COMPUSTAT, including data for payout policy and indicators of the $\mathrm{B} / \mathrm{S}$ conflict.

Our empirical analyses include both firm- and bond-level regressions. Because the firm-level data are available in earlier years, the samples for risk-taking and payout policy regressions extend back to 1996, the starting year of the RiskMetrics database. This increases the sample sizes and provides more comparability with prior studies, which typically employ multiple years' data. ${ }^{7}$ Our sample for the cost of debt regressions is an unbalanced panel between 2001 and 2005 , with 6,252 bond-year and 1,610 firm-year observations. ${ }^{8}$

\footnotetext{
${ }^{5}$ For example, Chava et al. (2010) show that $82.7 \%$ of newly issued corporate bonds are senior unsecured. In our sample the number of issues per firm is 3.88, which matches closely the statistics in Cremers et al. (2007) based on various types of bonds, further suggesting that our bond coverage is not significantly different from the literature.

${ }^{6}$ COMPUSTAT sets a year to be $t$ if the fiscal year end-of-month for the firm is between June, year $t$ and May, year $t+1$. Since our bond data are at the end of March, the year $t$ in the bond data corresponds to year $t-1$ in COMPUSTAT. This can also alleviate the endogeneity concern as most of the financial and governance variables are in place before we calculate spreads.

${ }^{7}$ As pointed out by Bertrand et al. (2004), a concern for the DID specification with multiple years' data is that the standard errors may be severely underestimated. In unreported analysis, we follow their correction method and create an alternative sample with one year's observation before SOX and one year after, by averaging a firm's preSOX (and post-SOX) observations into a single observation. We find that our results are qualitatively similar. We also do the same for the cost of debt samples, and find similar results as well.

${ }^{8}$ Sample sizes may vary depending on the proxies for the $\mathrm{B} / \mathrm{S}$ conflict. This sample size refers to using $\mathrm{S} \& \mathrm{P}$ credit rating as a proxy for the credit condition of a firm. Our results are qualitatively similar for a sample formed by randomly selecting one issue from all the issues of a firm in a given year. The results are also similar if the sample consists of bonds that appear at both 2002 and 2005. This ensures that we calculate the post-SOX change of bond spread for the same bond. Our results are also similar for two of the four models with respect to the four B/S conflict proxies, if we average the issue-level variables (bond spread, modified duration, convexity, and bond age) into firm-
} 
Our samples include firms with dual-class stocks as well as finance and utility companies. In unreported analysis, we exclude these firms and our results are substantially similar.

\subsection{Relevant SOX Provisions and Timelines}

The Sarbanes-Oxley Act was signed into law on July 30, 2002. In February 2002, the SEC requested the exchanges to improve their governance listing standards. In August and October 2002 respectively, the NYSE and NASDAQ submitted proposed changes to the SEC. These proposals were approved with minor changes in November 2003. Given the corporate climate at the time, the ex-ante probability of disapproval was minimal. Therefore, 2002 is appropriate to serve as the treatment year in our DID methodology. The compliance statistics reported later are consistent with this assumption.

The Sarbanes-Oxley Act requires audit committees to be fully independent. The three major exchanges, NYSE, NASDAQ, and AMEX further require their listed firms to have a majority of independent directors. Because we study the effect of board independence on the cost of debt, it seems appropriate to use the majority independence requirement to identify noncompliant firms. However, for two reasons we choose to use both the majority independence requirement and the full independence requirement for audit committees to identify noncompliance. First, the fact that not every firm issues public bonds, together with the fact that a supermajority of the firms in our sample were already in compliance with the majority independence requirement before the enactment of SOX, reduces the number of noncompliant firms significantly. If we focus exclusively on the majority requirement to identify noncompliant firms we are left with only 20 firms and 65 bonds for the cost of debt regressions. This may raise the concern that our results are driven by a small number of "outliers". Second, the increased workload and liabilities of

level variables by taking the weighted averages of the issue variables of a firm in a given year, with the weight being the size of the issue as a fraction of the total issue sizes. 
independent directors around the time when SOX was enacted (Linck et al., 2009), suggest that the independent vacancies on audit committees are more likely to be filled by externally recruited new directors, rather than the existing ones. In addition, the SOX requirement of at least one financial expert on audit committees should also increase the demand for new independent directors. ${ }^{9}$ These arguments suggest that a firm without a fully independent audit committee may choose to hire new independent directors, which makes the non-independence of audit committees a valid criterion to identify noncompliance. Indeed, using the RiskMetrics database, we find that $83 \%$ of the firms without an independent audit committee at 2002 increased their board independence after SOX, despite the fact that these firms already had a majority of independent directors before SOX. Prior studies have used both the majority and audit committee independence requirements to identify noncompliant firms. For example, while Duchin et al. (2010) define noncompliance based on audit committee independence, Armstrong et al. (2013) focus on majority independence. Specifically, we define a firm as noncompliant if at 2002 it did not have a majority of independent directors or a fully independent audit committee, and became majority independent or, in the case of audit committee non-independence, increased its board independence post SOX. To determine whether a firm increased board independence post SOX, we compare the independence at 2002 with the maximum value of independence between 2003 and $2005 .{ }^{10}$ The above definition of noncompliance ensures that each of the

\footnotetext{
${ }^{9}$ This may raise the concern that our results on the effect of board independence on the cost of debt could be attributed to the effect of independent financial expert. This possibility is not inconsistent with our argument, because while we focus on the motivation of independent directors to monitor management in the interest of shareholders, effective monitoring may require different areas of expertise with financial expertise as one of them. But sorting out the motivation and the ability is beyond the scope of this paper.

${ }^{10}$ Our results are even stronger if we compare board independence at 2002 with that of 2005 to determine whether a firm increased independence after SOX. We use the maximum value of board independence between 2003 and 2005 in our primary analysis to increase the number of noncompliant firms. Note that this definition of noncompliance means that firms that did not have a majority of independent directors or a fully independent audit committee at 2002 and did not increase their board independence post SOX were classified as compliant. Our results are similar if we drop these firms from the sample.
} 
noncompliant firms indeed increased its independence after SOX. Our definition of noncompliance results in 71 noncompliant firms with 260 bonds at $2002 .{ }^{11}$ In unreported analysis, we find that our major results are robust to the definition of noncompliance based on majority independence only.

The exchanges required firms to adopt the new governance standards during their first annual meeting after January 15, 2004, but no later than October 31, 2004. Firms with classified boards were given until the second annual meeting to comply, but no later than December 31, 2005. Therefore, it is appropriate to end our sample at 2005 for the implementation of the DID strategy. We thus have two years on or before 2002, the treatment year, and three years thereafter.

\subsection{Variables}

\subsubsection{Board Independence}

RiskMetrics defines a director to be independent if she is not a current employee of the firm or affiliated with the firm. This definition closely follows that of the exchanges, but is somewhat stricter (Chhaochharia and Grinstein, 2009). NYSE and NASDAQ classify a director as independent even if she was a former employee of the firm, provided that her employment terminated at least three years prior to the directorship. In addition, the two exchanges classify an affiliated director as independent if her business transactions with the firm are inconsequential. In contrast, regardless of the termination date and transaction amount, a director is regarded as non-independent by RiskMetrics if she had worked for the firm, or if she has any business transactions with the firm. Since RiskMetrics does not provide the amount of transactions, we follow Chhaochharia and Grinstein (2009) and partially adjust the independence status in the

\footnotetext{
${ }^{11}$ These numbers refer to the cost of debt sample with credit rating as the measure of the $\mathrm{B} / \mathrm{S}$ conflict. Because Zscores include a significant number of missing observations, the number of noncompliant firms (bonds) based on Zscore as the $\mathrm{B} / \mathrm{S}$ conflict proxy is only 32 (104). Because the samples on risk-taking and payout policy are not confined to public bonds, they have much larger numbers of the noncompliant firms. For example, the number of noncompliant firms for the risk-taking sample is 191.
} 
data by re-classifying an affiliated director as independent if her former employment with the firm had ended for at least three years, the director does not currently provide professional services to the firm, and she is not an interlocking director. ${ }^{12}$ As pointed out by Chhaochharia and Grinstein (2009), the stricter definition of independence by RiskMetrics should make it harder to detect a significant relation between independence and dependent variables, because some noncompliant firms according to RiskMetrics actually may be compliant.

\subsubsection{Bond Spread}

We calculate the yield spread of a bond as the difference between the bond's yield-to-maturity (YTM) and the YTM of the Treasury bond matched by the closest maturity. As a robustness check, we also calculate spreads by the difference between the YTM of a bond and the linearlyinterpolated YTM of the Treasury bond with identical maturity. The results are similar.

\subsubsection{Indicators of the Agency Conflict Between Shareholders and Bondholders}

Because a firm with higher default risk or more debt is expected to have severer $\mathrm{B} / \mathrm{S}$ conflict, we use credit condition and leverage as indicators of the degree of the conflict (Bodie and Taggart, 1978; John and John, 1993). Our first proxy of credit condition is the S\&P long-term issuer credit rating. It is notable that this rating is a measure of the creditworthiness of the firm as a whole rather than any of its bonds. We also use Altman's Z-score (Altman, 1968) and interest coverage ratio (Asquith et al., 1994) as two alternative measures of credit condition. A lower Zscore or interest coverage ratio indicates that the firm is closer to financial default.

\subsubsection{Managerial Risk-Taking}

\footnotetext{
${ }^{12}$ In unreported analysis, we further redefine all affiliated directors as independent regardless of the amounts of their business transactions. This is likely to have reclassified too many affiliated directors into independent directors. As a result, the number of noncompliant firms at 2002 shrank dramatically to only 4 (with 24 bonds) for the cost of debt sample; hence the results should be interpreted with caution. Nonetheless, our major results based on this reclassification of independence are similar to the reported results.
} 
We follow many others and use equity volatility as the primary measure of managerial risktaking (e.g., Brick et al., 2012). This measure is necessarily noisy because volatility is affected by market factors beyond risk-taking. Therefore, in the robustness checks we also examine the impact of board independence on several corporate policies that may indicate managerial risktaking. Because the distribution of volatility is highly skewed, we take the log of this variable.

\subsubsection{Payout Policy}

We calculate the dividend payouts and stock repurchases in our primary analysis following Grinstein and Michaely (2005), where repurchases include both common and preferred stocks. The results are similar if we exclude preferred stocks (Grullon and Michaely, 2002), or use treasury common stocks in the calculation of repurchases (Fama and French, 2001).

Because it may take some time for the new independent directors to influence corporate decision making, we calculate the risk-taking and payout variables in the following year.

\subsubsection{Control Variables}

We follow prior studies to control for a number of variables in our regressions. The cost of debt regressions include both issue- and firm-level control variables. The issue-level variables include modified duration and convexity to proxy for the systematic risk of bond returns, and bond age to indicate liquidity. ${ }^{13}$ Older bonds are generally less liquid and hence may have higher spreads, ceteris paribus (Klock et al., 2005). The firm-level controls include financial variables and rating dummies. ${ }^{14}$ The financial controls include leverage, firm size, ROA, market-to-book

\footnotetext{
${ }^{13}$ In unreported analysis we also control for four indicators of bond covenants, including investment restrictions, financing restrictions, dividend restrictions, and event-risk restrictions. The definitions of these dummy variables follow Chava et al. (2010). Our results are similar.

${ }^{14} \mathrm{We}$ do not control for governance variables in our primary analysis to preserve the sample sizes. In unreported robustness analysis, we control for a number of governance variables following the literature, including compensation vega and delta (Shaw, 2012), board size (Anderson et al., 2004), institutional and block holdings (Bhojraj and Sengupta, 2003; Cremers et al., 2007), the G-index (Klock et al., 2005), the L-index (Bradley and Chen, 2011), and classified board dummy (Chen, 2012). The results are similar except for those with respect to interest coverage ratio.
} 
ratio, and sales growth rate (Bhojraj and Sengupta, 2003; Anderson et al., 2004). We also control for firm age to account for the possibility that more established firms may have lower credit risk. We control for rating dummies based on the 7 categories of S\&P ratings in Ashbaugh-Skaife et al. (2006). We also control for equity volatility, dividend payout, and stock repurchase in the current year in the cost of debt regressions, to examine whether these variables are indeed associated with a higher cost of debt. Nonetheless, we do not expect that these variables fully account for the adverse effect of board independence on bondholders, because the $\mathrm{B} / \mathrm{S}$ conflict also resides in other aspects of corporate actions, some of which may be even unobservable. In the risk-taking regressions, we control for CEO compensation vega and delta, CEO tenure and age, firm size, return on assets (ROA), market-to-book ratio, sales growth rate, firm age, R\&D expense, capital expenditure, leverage, cash balance, and number of business segments (Coles et al., 2006; Cheng, 2008). We also control for the lagged equity volatility to alleviate the omitted variable bias (Brick et al., 2012). The control variables in the payout regressions include CEO tenure, firm size, ROA, market-to-book ratio, sales growth rate, firm age, leverage, cash balance, CEO shareholdings, CEO un-exercisable and exercisable options, and stock return (Hu and Kumar, 2004; Skinner, 2008; Sharma, 2011).

To account for outliers, we take the $\log$ of, or winsorize all variables at the $1^{\text {st }}$ and $99^{\text {th }}$ percentiles.

\subsection{Summary Statistics}

Table 1 reports the summary statistics of the major variables, the compliance trend, and the comparisons of the key variables of interest between the noncompliant and compliant firms. Panel A lists the summary statistics. Except for the variables that are unique to the cost of debt regressions which are reported at the bond level, the summary statistics for other variables are 
reported at the firm level for a sample with non-missing common variables in the volatility and payout regressions. For the cost of debt regressions we report both the statistics for the full sample and, pursuant to our purpose in this paper, the statistics conditional on the expected severity of the B/S conflict. To save space, we only report the sub-sample statistics of yield spread, board independence, and the four indicators of the B/S conflict stratified by the median rating in the sample (BBB+). The summary statistics show that the mean (median) spread for the full sample is $2.46 \%(1.53 \%)$. The bond spreads in our sample are slightly larger than those in the literature (Bhojraj and Sengupta, 2003; Anderson et al., 2004; Klock et al., 2005), presumably reflecting our more recent time period. Our sample also shows a mean (median) board independence of $0.68(0.71)$. The high proportion of independent directors in our sample firms is consistent with the statistics reported in related studies over a comparable time period (e.g., Chhaochharia and Grinstein, 2009; Armstrong et al., 2013), and the upward trend in board independence over time (Linck et al., 2009).

As expected, the sub-sample statistics show that low-rated firms have higher spreads and leverage, and lower Z-scores and interest coverage ratios. High-rated firms have slightly higher board independence than low-rated firms (0.75 vs 0.73$)$. An unreported $t$-test indicates that the difference is statistically significant. ${ }^{15}$

Panel B presents the compliance trend between 2000 and 2005. Because these statistics are at the firm level, they are based on the sample with non-missing common variables in the volatility and payout regressions. We report the annual statistics of board independence, as well as the fractions of firms without majority independent boards or fully independent audit committees. ${ }^{16}$

\footnotetext{
${ }^{15}$ This result is based on statistics reported at the issue level. If keeping only one observation per firm in a given year, high-rated firms still have slightly higher board independence than low-rated firms (0.76 vs 0.73$)$.

${ }^{16}$ Note that because the definition of noncompliance requires the comparison between board independence before and after SOX, it is not convenient to list the annual fraction of the noncompliant firms. For example, if the year is
} 
The statistics suggest a general upward trend for board independence even before the enactment of SOX. We find a similar pattern for an even earlier time period. The positive trend for independence presumably reflects the effect of shareholder activism (Gillan and Starks, 2007), and the 1999 NYSE rule for independent audit committees. Despite the uptrend of independence over time, however, Panel B shows a significant increase of independence between 2002 and 2003 relative to other years, which is right after SOX took effect. Therefore, it is appropriate to use 2002 as the treatment year in our DID methodology.

It is notable that a portion of the firms were still not compliant as required by SOX by 2005 . This puzzle is shared by other studies using the RiskMetrics data (e.g., Chhaochharia and Grinstein, 2009; Kim and Lu, 2012). Our manual search of a random sample suggests that a vast majority of these firms actually declared compliance. Therefore, this puzzle seems to be driven by the stricter definition of independence based on RiskMetrics than the exchanges.

Panel C compares the changes in some key variables of interest between 2002 and 2005 for the noncompliant and compliant firms. We also compare the changes conditional on credit ratings. The results based on other measures of the $\mathrm{B} / \mathrm{S}$ conflict are qualitatively similar. We report the statistics for independence at both the issue and firm levels. We also report the number of firms/bonds that the statistics are based on. ${ }^{17}$

As expected, the independence of the noncompliant firms increased significantly more than that of the compliant firms regardless of the sample. On average, the noncompliant firms added 1.26 more independent directors in the post-SOX period. At the same time, the noncompliant

after 2002 (post-SOX), to calculate the fraction of the firms that are noncompliant based on our definition, we need to compare the board independence at that year with the maximum value of independence post-SOX, which is not meaningful for the years after SOX.

${ }^{17}$ Because the calculation of the statistics essentially requires the bonds to be available at both 2002 and 2005, the numbers of noncompliant firms/bonds reported in the panel are smaller than the numbers of noncompliant firms/bonds mentioned earlier (71/260). 
firms removed more inside and linked (affiliated) directors than the compliant firms, leaving board sizes unchanged. Therefore, the statistics suggest that rather than simply adding more independent directors, noncompliant firms replaced some of their non-independent directors with the independent directors. To ensure that the noncompliant firms identified through the audit committee independence requirement did indeed increase their board independence post SOX, we also compare the change of board independence of firms without fully independent audit committees but with majority independent boards, with that of the compliant firms. The statistics are consistent with our expectations - the noncompliant firms identified through the audit committee independence requirement added 0.92 more independent directors than the compliant firms. However, the statistics in Panel $\mathrm{C}$ do not detect a significant difference in the changes of volatility and payout policy variables between the noncompliant and compliant firms.

Panel $\mathrm{C}$ also shows that the changes in bond spreads are similar between the noncompliant and compliant firms, despite a significantly greater increase in board independence by the former. However, the sub-sample statistics suggest that the similarity between the changes of bond spreads holds only for firms with high ratings. For low-rated firms, the bond spreads of the noncompliant firms increased significantly more relative to the compliant firms. Therefore, these results provide preliminary evidence consistent with a differential impact of board independence on the cost of debt conditional on the $\mathrm{B} / \mathrm{S}$ conflict.

\section{Methodology and Empirical Results}

In this section we first discuss our empirical model specifications. Next we examine the determinants of the propensity score - the probability of being noncompliant at 2002, to be used in weighting the DID regressions. We then present our primary analysis, the examination of the differential impact of board independence on the cost of debt conditional on the expected $\mathrm{B} / \mathrm{S}$ 
conflict. Finally, as some examples of the costs of independence for bondholders, we study the effects of board independence on managerial risk-taking and payout policy.

\subsection{Empirical Specification}

Our DID models for the cost of debt regressions are as follows:

$$
\begin{aligned}
& \text { Bond Spread }_{i, j, t}=\beta_{0}+\beta_{1} * \text { Noncomplia } n t_{i} * \text { Post }- \text { SOX }+\beta_{2} * \text { Post }- \text { SOX } \\
& +\overline{\text { Control Variables }}{ }_{i, j, t} \cdot \overline{\beta_{3}}+\alpha_{i}+\varepsilon_{i, j, t}
\end{aligned}
$$

In the above equation, Bond Spread $_{i, j, t}$ is the yield spread of bond $j$ of firm $i$ at year $t$. Noncompliant $_{i}$ is a dummy variable that equals one if firm $i$ is not compliant at 2002 as defined previously, and zero otherwise. Post-SOX is a dummy variable that equals one if the observation is on or after 2003, and zero otherwise. The control variables are as described in Section 2.3.6. $\alpha_{i}$ is the fixed firm effect. ${ }^{18}$ Our primary coefficient of interest is $\beta_{1}$, which represents the difference between the post-SOX changes of the dependent variables of the noncompliant and compliant firms. Standard errors are adjusted for heteroscedasticity and, in light of the issue-level regressions, are clustered at both the bond level (recognizing the autocorrelation) and firm-year level (recognizing the correlations of different bonds of the same firm in a given year).

Our focus in this study is to analyze a potentially differential effect of board independence on the cost of debt, conditional on the severity of the B/S conflict. Two methods could serve this purpose. First, we could conduct sub-sample analyses according to specification (1), contingent on different levels of the $\mathrm{B} / \mathrm{S}$ conflict. However, our previous discussion suggests that the numbers of noncompliant firms/bonds are generally small, which may raise the concern that our results are driven by the undue influence of some outliers. Because the small-number issue is more acute for sub-sample analysis, we focus on the second method to study a differential effect

\footnotetext{
${ }^{18}$ Our major results are similar if controlling for firm as well as CEO fixed effects. The CEO fixed effect considers the possibility that the innate attributes of a CEO may affect corporate actions and the cost of debt.
} 
(though still use the sub-sample analysis as a robustness check), which utilizes the full sample

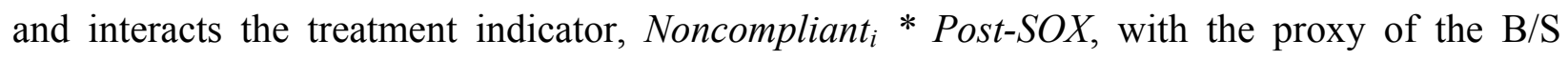
conflict. A significant interaction term is consistent with a differential effect. This method has the added benefit of not being subject to another concern for sub-sample analysis, that the division of the sample into sub-samples is essentially arbitrary. However, sub-sample analysis has the advantage of not forcing the equality of the coefficients for the control variables across the sub-samples. In light of this issue, we also interact each of the control variables except for the firm fixed effects with the $\mathrm{B} / \mathrm{S}$ conflict proxies. The above discussion suggests the following primary specification to study a differential impact of board independence, where we have abbreviated the $\mathrm{B} / \mathrm{S}$ conflict proxy as " $B S C P$ " to save space:

$$
\begin{aligned}
& \text { Bond Spread }_{i, j, t}=\beta_{0}+\beta_{1} * \text { Noncomplia }_{n} * \text { Post }- \text { SOX } * \text { BSCP }_{i, t}+\beta_{2} * \text { Noncomplia }_{i} * \text { Post }- \text { SOX } \\
& +\beta_{3} * \text { Noncomplia }_{n} * \mathrm{BSCP}_{i, t}+\beta_{4} * \text { Post }-\operatorname{SOX} * \mathrm{BSCP}_{i, t}+\beta_{5} * \text { Post }-\mathrm{SOX}+\beta_{6} * \\
& \text { BSCP }_{i, t}+\overline{\text { Control Variables }_{i, j, t}} * \operatorname{BSCP}_{i, t} * \overline{\beta_{7}}+\overline{\text { Control Variables }_{i, j, t}} * \overline{\beta_{8}}+\alpha_{i}+\varepsilon_{i, j, t}
\end{aligned}
$$

Our DID models for the regressions on equity volatility and payout policies are similarly specified, except that the regressions are at the firm level (hence standard errors are clustered at the firm level):

$$
\begin{aligned}
\text { Volatility (Payout })_{i, t+1} & =\beta_{0}+\beta_{1} * \text { Noncomplia }_{n t} * \text { Post }- \text { SOX }+\beta_{2} * \text { Post }- \text { SOX } \\
& +\overline{\text { Control Variables }}{ }_{i, t} \\
\beta_{3} & +\alpha_{i}+\varepsilon_{i, t}
\end{aligned}
$$

In (3), Volatility (Payout) $)_{i, t+1}$ is the equity volatility (payout) of firm $i$ at year $t+1$.

\subsection{Propensity Score Analysis}

An important assumption of the DID method is that the treatment and control firms are similar in the sense that the underlying time effect would have followed parallel paths for both in the absence of the treatment. However, given that board independence is endogenously determined (Hermalin and Weisbach, 2003), the assumption of the similarity between the noncompliant and 
compliant firms is unlikely to be satisfied. A common solution to this problem is to match treatment firms with control firms based on the propensity score (Rosenbaum and Rubin, 1983). Imbens and Wooldridge (2009) further recommend the combination of regressions with propensity score matching or weighting. Hirano et al. (2003) show that weighting based on the following algorithm leads to an efficient estimate of the average treatment effect on the treated: ${ }^{19}$

$$
w=\left\{\begin{array}{l}
1 \text { for the noncompliant firms } \\
p /(1-p) \text { for the compliant firms }
\end{array}\right.
$$

where $p$ is an estimate of the propensity score. ${ }^{20}$ The above weighting scheme is intuitive, since it gives a greater weight to compliant firms with higher propensity score, which are presumably more similar to the noncompliant firms. We use the propensity score weighted DID regressions in our primary analysis, and propensity score matching in the robustness checks.

We rely on previous studies on the determinants of board composition and audit committee independence for the covariates of the propensity score (Klein, 2002; Boone et al., 2007; Linck et al., 2008; Lehn et al., 2009). Our selection of the covariates is a balance of comprehensiveness and the need to preserve the sample sizes, since weighting based on the propensity score requires the availability of its determinants. The covariates in our primary regression include firm size, number of business segments, free cash flow, market-to-book ratio, sales growth rate, R\&D expense, CEO shareholdings, a dummy variable indicating whether the CEO sits on the nomination (compensation) committee, shareholdings of independent directors, and ROA. This results in a sample size of 1,010 firms at 2002. Except for ROA, the covariates are based on the

\footnotetext{
${ }^{19}$ This is the case in our study, because the post-SOX change of the compliant firms essentially serves as an estimate of the change of the noncompliant firms in the absence of the treatment.

${ }^{20}$ The exact implementation of the method in Hirano et al. (2003) requires a nonparametric estimate of the propensity score, which could be obtained through logit estimation with flexible functions of the covariates. However, the previous literature on the determinants of board composition focuses on the linear function of the covariates. Because we rely on these studies to identify the covariates of the propensity score, we also focus on the linear form. In this regard, our method is an approximation of the method proposed in Hirano et al. (2003). We note that many prior studies also have this feature (e.g., Malmendier and Tate, 2009; Stuart and Yim, 2010; Yim, 2013).
} 
three hypotheses on board composition as in Boone et al. (2007): scope of operation, monitoring, and negotiation. Because we use these variables to predict noncompliance at 2002, we lag them by one year in the regressions. In Panel A of Table 2, we compare these variables for the noncompliant and compliant firms. The statistics show several significant differences, mainly for the governance variables. Specifically, compared with the compliant firms, the CEOs of the noncompliant firms tend to hold more equity shares and are more likely to sit on the committees. Besides, independent directors of the noncompliant firms also have more shareholdings.

In Panel $\mathrm{B}$ we run logit regressions on a dummy variable indicating whether a firm is noncompliant or not at 2002. In addition to the control variables described above, we also include the Fama-French 48-industry dummies. Consistent with the statistics in Panel A, Model 1 suggests that firms with more CEO shareholdings, firms whose CEOs sit on nomination or compensation committees, as well as firms with more independent director shareholdings are more likely to be noncompliant. The first three results are consistent with the negotiation hypothesis that a powerful CEO tends to select non-independent directors. The last result is consistent with the substitution between board independence and the shareholdings of independent directors in monitoring management. Interestingly, some variables that are not significantly different based on the $t$-tests in Panel A (firm size, free cash flow, and market-tobook ratio), are significant in these regressions. The reverse is true for number of business segments and R\&D expense, perhaps reflecting industry effects. The signs on firm size and market-to-book ratio are inconsistent with prior studies, presumably due both to the difference in samples and our inclusion of audit committee independence in defining noncompliance. ${ }^{21}$ But

\footnotetext{
${ }^{21}$ Indeed, if we run logit regressions on the noncompliance dummy based solely on majority independence requirement, these two variables are no longer significant. Conditioning the regressions on firm sizes, Linck et al. (2008) find that the monitoring cost factor extracted from three variables including market-to-book ratio, is not
} 
we note that another proxy for firms' growth opportunities, the sales growth rate, is not significant. Lehn et al. (2009) present evidence of a nonlinear effect of firm size on board composition. Therefore, in Model 2 we include the squared term of firm size as an additional variable. Indeed, the results are consistent with a non-monotonic impact of firm size on noncompliance.

In Model 3 we include a more comprehensive set of control variables, which reduces the sample to 850 observations. Note that none of these additional variables are significant. Because both Models 1 and 3 include a number of insignificant variables, we entertain a fourth model with only the significant determinants of the propensity score. The results are reported in Model 4. We use Model 1 to estimate the propensity score in our primary analysis. ${ }^{22}$ In unreported analysis, we find that our results are similar using the other three models.

An important requirement to implement the propensity score method is the satisfaction of the balancing property, that the treatment and control firms are indeed similar in terms of the propensity score and its covariates. In unreported analysis we find that among the four models in Panel B, only Model 1 satisfies the balancing property, which is another reason we employ this model in our primary analysis.

\subsection{Board Independence and the Cost of Debt}

Using the estimated propensity score $p$ and the weighting scheme in (4), we first examine the average effect of board independence on the cost of debt with specification (1). The results are reported in Model 1 of Table 3. The coefficient on Noncompliant * Post-SOX is positive but not significant, consistent with the similarity between the post-SOX changes of bond spreads of the

significantly related to board independence for the largest firms in their sample (Table 5 in their study), which are comparable to the sample firms in our study.

${ }^{22}$ Our results are similar for a sample with propensity score on the "common support" (between minimum score for the treated and maximum score for the control firms). The results are also similar for a "trimmed" sample with propensity score between 0.1 and 0.9 , the efficiency bound suggested by Crump et al. (2009). 
noncompliant and compliant firms as shown in Table 1. In light of the benefits and costs of independent directors on bondholders, and given that we control for equity volatility and payout variables in the model, this result suggests that the costs of independent directors on bondholders other than their potential effects on managerial risk-taking and payout policy may balance out their benefits. The insignificant effect of board independence on the cost of debt as we document is in contrast with most related studies, which find a beneficial effect of independence on bondholders (Bhojraj and Sengupta, 2003; Anderson et al., 2004; Ertugrul and Hegde, 2008).

As expected, equity volatility is associated with a higher cost of debt, consistent with the idea that managerial risk-taking is detrimental to bondholders' wealth. However, the two payout variables are not significant, which may suggest that the detrimental effect of a wealth transfer through corporate payouts and their beneficial effect of "signaling" of future profitability are both present for bondholders (Maxwell and Stephens, 2003; Jun et al., 2009). Other significant control variables generally have their expected signs except for bond age and firm age. Though predicted to be positive (negative), bond (firm) age is negatively (positively) related to spread.

In Models 2-5 of Table 3 we follow specification (2) to examine a differential impact of board independence on the cost of debt conditional on the four indicators of the expected $\mathrm{B} / \mathrm{S}$ conflict as discussed in Section 2.3.3, respectively. Because higher rating (Z-score, interest coverage ratio) suggests less intensive $\mathrm{B} / \mathrm{S}$ conflict but higher leverage indicates the opposite, a differential effect implies that Noncompliant * Post-SOX * Rate (Z-score, Int_cov) and Noncompliant * Post-SOX * Leverage should be significant but with opposite signs. Indeed, the results in Table 3 show that Noncompliant * Post-SOX * Rate (Z-score, Int_cov) is negative and significant, and Noncompliant * Post-SOX * Leverage is positive and significant, suggesting that with the intensification of the $\mathrm{B} / \mathrm{S}$ conflict, board independence is increasingly costly to bondholders. The 
coefficients on Noncompliant * Post-SOX * BSCP (B/S conflict proxy) and Noncompliant * Post-SOX also suggest that while board independence is beneficial to bondholders under mild $\mathrm{B} / \mathrm{S}$ conflict, it is detrimental to bondholders when the conflict is severe. For example, because in our sample the lowest rating value is 7 (B-), the results in Model 2 suggest that the net coefficient on Noncompliant $*$ Post-SOX is $1.571(=2.831-0.180 * 7)$ under the lowest rating and hence the severest $\mathrm{B} / \mathrm{S}$ conflict. On the other hand, since the highest rating is 22 (AAA), the net coefficient on Noncompliant * Post-SOX is $-1.129(=2.831-0.180 * 22)$ under the highest rating and the mildest conflict. With regard to the different rates of changes of benefits and costs of board independence on bondholders in relation to the $\mathrm{B} / \mathrm{S}$ conflict, this evidence suggests that while the costs of board independence are smaller than its benefits when the $\mathrm{B} / \mathrm{S}$ conflict is small, the costs increase at a faster rate and eventually exceed the benefits when the conflict intensifies. This result also implies a potentially much stronger effect of board independence on the cost of debt given a certain degree of the $\mathrm{B} / \mathrm{S}$ conflict as compared with the average effect. We show that this is the case when discussing the sub-sample analysis.

The results in Table 3 also suggest a differential effect of several control variables on the cost of debt. In particular, in three of the four models we find equity volatility is increasingly positive with the amplification of the $\mathrm{B} / \mathrm{S}$ conflict, which is consistent with our argument that the agency costs of debt are increasing with the severity of the conflict. In two of the four models we also document a similar effect for cash dividends and stock repurchases.

In Table 4 we employ the sub-sample analysis to examine the robustness of our results. As discussed earlier, a disadvantage of this analysis is that the division of the full sample into subsamples is arbitrary. The finer the division, the more homogeneous the firms within each subsample in terms of their B/S conflict, the better it serves our purpose of identifying the effect of 
board independence on the cost of debt conditional on the $\mathrm{B} / \mathrm{S}$ conflict. However, the small number of noncompliant firms/bonds in our study does not permit a very fine division. Therefore, we choose to divide the full sample into two sub-samples based on the median value of credit ratings (Z-scores, interest coverage ratios, leverages) in the sample. ${ }^{23}$

The results in Table 4 show an opposite effect of board independence on the cost of debt depending on the level of the $\mathrm{B} / \mathrm{S}$ conflict and, with the exception of the results with respect to interest coverage ratio, all results are significant. ${ }^{24}$ In unreported analyses, we find that the coefficients are also statistically different across the sub-samples based on the Chow tests. Consistent with the interaction results in Table 3, the sub-sample results in Table 4 show that while exogenously increasing independence results in an increase in bond spreads for firms with severe $\mathrm{B} / \mathrm{S}$ conflict, it leads to a decrease in spreads when the conflict is mild. ${ }^{25}$

Turning to the economic significance of the results, we note that the average board size of the low-rated sample is 10.45 . As shown in Table 1, the mean spread and the difference between the increases of independence of the noncompliant and compliant firms of low-rated firms are $3.07(\%)$ and 0.13 , respectively. Therefore, the coefficient on Noncompliant * Post-SOX, 0.803, suggests that adding one more independent director to the average firm of the low-rated sample (to replace a non-independent director) results in a substantial $19.3 \%(=0.803 / 0.13 *(1 / 10.45)$ 13.07) increase in its cost of debt. Similar calculation suggests that adding one more independent director to the average high-rated firm results in a significant $17.3 \%$ decrease in the cost of

\footnotetext{
${ }^{23}$ The median values are based on the issue-level samples. Our results are similar if we divide the full sample based on the firm-level median values.

${ }^{24}$ If we run regressions respectively on sub-samples with interest coverage ratios greater than their $75^{\text {th }}$ percentile and less than the $25^{\text {th }}$ percentile, which presumably include firms with more homogenous $\mathrm{B} / \mathrm{S}$ conflicts, we find that the negative effect is significant at the $5 \%$ level and the positive effect is weakly significant at the $10.4 \%$ level. The magnitudes of the coefficients are also larger than those in Models 5 and 6, consistent with expectations.

${ }^{25}$ In unreported analysis, we interact each control variable in Table 4 with a pre-SOX dummy and the post-SOX dummy, respectively. This considers the possibility that SOX may have changed the impact of a certain variable on the cost of debt. We find the results are qualitatively similar. We also do the same for the risk-taking and payout regressions, and document similar results as well.
} 
debt. ${ }^{26}$ Compared with related studies, the impact of board independence in our study is much larger. Different samples and time periods, as well as different empirical methodologies may provide some explanations for the difference in results. However, we believe that the most important reason for the difference is the conditioning of the regressions on the expected $\mathrm{B} / \mathrm{S}$ conflict. The sub-samples presumably have much more homogenous $\mathrm{B} / \mathrm{S}$ conflicts compared with full samples in other studies. As a result, the effects of board independence on the cost of debt within sub-samples may also be substantially larger. Consistent with this explanation, we note that the average effect of independence based on the full sample is insignificant in our study.

Similar to the interaction results in Table 3, Table 4 also suggests a differential impact of some control variables. Interestingly, depending on the $\mathrm{B} / \mathrm{S}$ conflict, the effects of dividend payout on the cost of debt are opposite to each other. While dividend payout benefits bondholders under mild $\mathrm{B} / \mathrm{S}$ conflict, it hurts bondholders if the conflict is severe. In contrast, the effect of stock repurchases is consistently negative, which suggests that repurchases may not be harmful to bondholders. As noted above, these results provide some evidence consistent with the two opposite but non-mutually exclusive roles of corporate payouts, wealth transfer and signaling, as documented in the literature (Maxwell and Stephens, 2003; Jun et al., 2009). These results also suggest the different roles of dividends and repurchases for bondholders.

\subsection{Board Independence and Managerial Risk-Taking and Payout Policy}

\footnotetext{
${ }^{26}$ This large effect of board independence in reducing the cost of debt, coupled with the beneficial effect of independence on shareholders, raises an interesting question: why firms with less $\mathrm{B} / \mathrm{S}$ conflict did not increase their independence sufficiently before SOX, since they still benefited from an externally-imposed higher independence standard due to SOX? One plausible explanation is the role management plays. As we argue and most empirical evidence supports, independent directors generally perform a more effective monitoring role, which may reduce managerial opportunism. Therefore, in the absence of external regulations, management may attempt to prevent the board from reaching its optimal composition. As a support to this argument, we note that our propensity score analysis in Table 2 suggests that a more powerful CEO as characterized by more shareholdings and committee memberships, is associated with lower board independence.
} 
Our argument in this study is that board independence may be beneficial as well as costly to bondholders due to the $\mathrm{B} / \mathrm{S}$ conflict. In the cost of debt regressions, we control for equity volatility and payout variables, in an attempt to examine whether the two examples of corporate actions, managerial risk-taking and corporate payout, are indeed detrimental to bondholders, and whether their adverse effects are increasing with the $\mathrm{B} / \mathrm{S}$ conflict. To provide some direct evidence of the role independent directors may play in these corporate outcomes, we examine in this subsection the effects of board independence on equity volatility, cash dividends, and stock repurchases, using specification (3). The results are reported in Table 5.

Model 1 shows that compared with compliant firms, equity volatility of noncompliant firms increased significantly post SOX. To gauge the economic significance of this result, we note from Panel C of Table 1 that the noncompliant firms overall increased their board independence by 0.17 more than the compliant firms. In our sample the average board size is 9.51 and the average equity volatility is -3.77 . So adding one more independent director results in a $0.64 \%$ increase in volatility for the average firm in the sample. Compared with some financial variables, the effect of board independence on firm risk is small, but not negligible.

Model 1 also suggests that firms on average decreased risk-taking after SOX as shown by a negative Post-SOX dummy. This evidence is consistent with the extant studies (e.g., Cohen et al., 2009; Bargeron et al., 2010), which argue that SOX discourages firms from taking risks. Given the positive effect of board independence on risk-taking, however, we provide a refined version of this argument that although many provisions of SOX may discourage risk-taking, a higher independence requirement nevertheless encourages risk-taking.

Model 1 also shows that several risk-taking policy variables, including R\&D expense, leverage, and cash balance are significantly associated with equity volatility, and the signs on 
these variables are consistent with expectations. In the robustness checks we further examine the effect of board independence on these variables.

The other two models in Table 5 examine the effect of board independence on payout policy. We do not document a significant effect of independence on either cash dividends or stock repurchases. These results are consistent with some studies (White, 1996; Farinha, 2003) but inconsistent with others (Hu and Kumar, 2004; Sharma, 2011). We note that among the related studies, ours is the only one that employs a natural experiment to solve the endogeneity problem.

In summary, our empirical analysis suggests that board independence is increasingly costly to bondholders with the intensification of the B/S conflict. Our evidence is consistent with the idea that though the benefits of independent directors dominate their costs when the $\mathrm{B} / \mathrm{S}$ conflict is mild, the costs may increase at a faster rate than the benefits when the conflict is severer, eventually catching up and exceeding the benefits at a certain degree of the conflict. In examining the effects of board independence on two corporate actions that may be detrimental to bondholders, we find a risk-increasing effect of higher independence. However, we do not detect a significant effect of independence on corporate payout policy.

\section{Robustness Checks}

\subsection{Propensity Score Matching}

Our primary empirical analysis employs propensity score weighted DID regressions. One advantage of this methodology is that it can preserve the sample size as much as possible. In addition to this method, Imbens and Wooldridge (2009) also recommend combining regressions with propensity score matching. We thus use the propensity score matched DID regressions to examine the robustness of our primary finding of a differential impact of board independence on the cost of debt conditional on the expected $\mathrm{B} / \mathrm{S}$ conflict. We entertain several matching 
algorithms: one-to-one matching without replacement, nearest neighbor matching with five compliant firms (if available) matched with each noncompliant firm, and kernel matching. The results based on these matching methods are reported in Table 6. To conserve space, we only report the results with respect to credit ratings, but note that the results on the other proxies of the $\mathrm{B} / \mathrm{S}$ conflict are similar. The results in Table 6 are consistent with those in Table 3, thus providing support to our primary findings.

\subsection{Board Independence and Risk-Taking Corporate Policies}

In the primary empirical analysis we use equity volatility as a measure of managerial risktaking. As discussed earlier, a drawback of this measure is that volatility is affected by factors beyond the management control. Therefore, in this subsection we employ the propensity score weighted DID methodology to examine the effects of board independence on three corporate policies that are commonly used as indicators of managerial risk-taking, R\&D expense (Cohen et al., 2009), leverage (Cain and Mckeon, 2013), and cash balance (Bargeron et al., 2010). These variables are also significantly associated with equity volatility as shown in Table 5 . The control variables in the policy regressions are similar to those in the volatility regression, except that we do not control for the policy variables themselves and the lagged volatility. ${ }^{27}$ In the leverage regression we also control for PPE. The results are reported in Table 7.

Model 1 shows that board independence is positively associated with R\&D expense, but the effect is not significant. Model 2 suggests a similar effect for leverage. But in both Models a majority of the control variables are not significant. If we drop the insignificant variables from the leverage model, board independence becomes significant at the 5\% level, as shown in Model 3. Dropping the insignificant variables from the R\&D model does not alter the results. Finally,

\footnotetext{
${ }^{27}$ Our results are similar if keeping the lagged volatility in the regressions, or controlling for the lagged policy variables in the respective models.
} 
the results in Model 4 show that independent directors set lower cash balances, which also indicates risk-taking behavior. By and large, Table 7 provides some evidence consistent with the equity volatility results, corroborating the idea that an exogenous increase of board independence leads to more managerial risk-taking.

\section{Conclusion}

We reexamine the effect of board independence on the cost of debt, with a focus on a potentially differential impact conditional on the expected severity of the agency conflict between shareholders and bondholders. Our thesis is that because independent directors generally act in the interest of shareholders, some of their monitoring functions may be costly to bondholders, in light of the conflict of interests between the two stakeholders. Recognizing both benefits and costs of board independence, and especially considering their possibly different rates of changes with the intensification of the $\mathrm{B} / \mathrm{S}$ conflict, a differential effect of independence on the cost of debt is expected.

Using SOX as a natural experiment and propensity score weighted DID regressions, we document empirical evidence that is consistent with this idea. While board independence significantly reduces the cost of debt when the $\mathrm{B} / \mathrm{S}$ conflict is mild, it substantially increases the cost of debt when the conflict is severe. We also find a risk-increasing effect of independence, providing some direct evidence on the costly corporate actions for bondholders that independent directors may be associated with.

Our study offers several insights into the academic literature and public policies. The divergent effect of board independence on the cost of debt provides clear evidence against the "one-size-fits-all" approach for regulations. It also offers another example in support of the argument that "good" governance from the perspective of one stakeholder may not be good for 
other stakeholders, especially under certain contingencies. Unlike the common perception in the literature that corporate governance matters more for bondholders when the default risk is higher, we show that not only the magnitude, but also the direction of the governance mechanism on the cost of debt may change with the credit condition of a firm. 


\section{Appendix Variable Definitions}

Variable

Spread

Per_ind

Ind_audit

Noncompliant

Rate

Z-score

Int_cov

Leverage

Volat

Dividend

Repurchase

Duration

Convexity

Bond age

Size

ROA

$\mathrm{Mb}$

Salesgrow

Firm age

Vega
Definition

Data Source

The difference between the yield-to-maturity (YTM) of a bond issue and S\&P Snapshot the YTM of the Treasury bond with the closest maturity.

Percent of independent directors to total board size. Because the definition of independence in RiskMetrics is stricter than that of the exchanges, we reclassify an affiliated director according to RiskMetrics as independent if she was a former employee of the firm but had terminated the employment for at least three years, does not provide any professional services to the firm, and is not an interlocking director.

Dummy variable that equals one if the audit committee of a firm is composed entirely of independent directors, and zero otherwise.

Dummy variable that equals one if independent directors were less than majority at 2002 but became majority over 2003 and 2005, or the audit committee was not composed entirely of independent directors at 2002 and the firm increased the independence of the whole board between 2003 and 2005, and zero otherwise.

Numerical coding of the S\&P long-term domestic issuer credit ratings (data280). Ranges from 1(debt in default) to 22 (AAA-rated). We then group the S\&P credit ratings into 7 categories to form the Grate variable. Specifically, Grate $=1$ if rating $<=\mathrm{CCC}+$; Grate $=2$ if $\mathrm{CCC}+<$ rating $<=\mathrm{B}+$; Grate $=3$ if $\mathrm{B}+<$ rating $<=\mathrm{BB}+$; Grate $=4$ if $\mathrm{BB}+<$ rating $<=\mathrm{BBB}+$; Grate $=5$ if $\mathrm{BBB}+<$ rating $<=\mathrm{A}+$; Grate $=6$ if $\mathrm{A}+<$ rating $<=\mathrm{AA}+$; Grate $=7$ if rating $>\mathrm{AA}+$. Rating dummies are based on Grate.

Altman's Z-score, composite score indicating the distance to financial default, defined as $(3.3 *($ data $15+$ data $16+$ data $18+$ data 49$) /$ data $6+$ $1.0 *$ data $12 /$ data $6+1.4 *$ data $36 /$ data $6+1.2 *($ data $4-$ data5)/data $6+0.6 *$ data $199 *$ data25/(data9+data34)). Interest coverage ratio (data13/(data 15 or data339 if data $15=0$ or data 15 is not available)).

Market leverage ratio ((data9+data34)/(data9+data34+data199*data25)). The log of the standard deviation of daily stock returns for at least 100 days over the year.

Annual cash dividends for common stock scaled by total assets (data26*data25/data6).

Annual repurchases of common and preferred stocks scaled by total assets (data115/data6).

The log of the modified duration of a bond.

The $\log$ of the convexity of a bond.

The log of the number of years since a bond was issued.

The log of market capitalization ( $\log ($ data $199 *$ data 25$))$.

Return on asset (data13/data6).

Market-to-book ratio ((data6-data60+data199*data25)/data6).

RiskMetrics

RiskMetrics

COMPUSTAT

COMPUSTAT

COMPUSTAT

COMPUSTAT

CRSP

COMPUSTAT

COMPUSTAT

S\&P Snapshot

S\&P Snapshot

S\&P Snapshot

COMPUSTAT

COMPUSTAT

COMPUSTAT

COMPUSTAT

COMPUSTAT

The log of the number of years since a firm was publicly traded.

The log of 0.001 plus the sensitivity of CEO option portfolio value to a

EXECUCOMP

0.01 change in the annualized standard deviation of stock returns, where the estimation of the sensitivity follows the "one-year approximation" (OA) method in Core and Guay (2002). Specifically, for the estimation inputs we use the annualized standard deviation of monthly stock returns 
Delta

over the past 60 months, and the average dividend yield over the past three years. Risk-free rates are the YTM of the Treasury bonds matched by the closest maturities.

\begin{tabular}{|c|c|c|}
\hline elta & $\begin{array}{l}\text { The log of } 0.001 \text { plus the sensitivity of CEO option and stock portfolio } \\
\text { value to a } 1 \% \text { change in stock price, where the estimation of the } \\
\text { sensitivity follows the OA method. Specifically, for the estimation inputs } \\
\text { we use the annualized standard deviation of monthly stock returns over } \\
\text { the past } 60 \text { months, and the average dividend yield over the past three } \\
\text { years. Risk-free rates are the YTM of the Treasury bonds matched by the } \\
\text { closest maturities. }\end{array}$ & EXECUCO \\
\hline CEO tenure & The $\log$ of 0.001 plus CEO tenure in years. & EXECUCOMP \\
\hline CEO age & The log of CEO age in years. & EXECUCOMP \\
\hline $\mathrm{R} \& \mathrm{D}$ & $\begin{array}{l}\text { \&D expenses scaled by total assets, missing values coded as zeros } \\
\text { ata46/data6). }\end{array}$ & COMPUSTAT \\
\hline Capexp & $\begin{array}{l}\text { et capital expenditure scaled by total assets, missing values coded as } \\
\text { ros ((data128-data107)/data6). }\end{array}$ & COMPUSTAT \\
\hline Cash balance & The $\log$ of cash balance scaled by total assets $(\log ($ data $1 /$ data 6$))$. & COMPUSTAT \\
\hline Segment & The log of number of business segments. & COMPUSTAT \\
\hline CEO shares & Percent shareholding of a CEO. & EXECUCOMP \\
\hline Unexercisable opti & $\begin{array}{l}\text { sPercent of the unexercisable options held by a CEO to total shares } \\
\text { outstanding. }\end{array}$ & EXECUCOMP \\
\hline Exercisable options & $\begin{array}{l}\text { Percent of unexercised exercisable options held by a CEO to total shares } \\
\text { outstanding. }\end{array}$ & EXECUCOMP \\
\hline Stock return & Cumulative annual stock return over the year. & CRSP \\
\hline PPE & Net PPE scaled by total assets (data8/data6). & COMPUSTAT \\
\hline Cash flow & Free cash flow ((data18-data14)/lagged data8) & COMPUSTAT \\
\hline G-index & $\begin{array}{l}\text { The sum of } 24 \text { dummy variables indicating the presence or absence of } \\
\text { firm-level antitakeover provisions or state-level antitakeover statutes. }\end{array}$ & RiskMetrics \\
\hline CEO nom & $\begin{array}{l}\text { Dummy variable that equals one if a CEO sits on her firm's nomination } \\
\text { or governance committee, or the firm does not have a nomination and } \\
\text { governance committee, and zero otherwise. }\end{array}$ & RiskMetrics \\
\hline CEO comp & \multicolumn{2}{|c|}{$\begin{array}{l}\text { Dummy variable that equals one if a CEO sits on her firm's compensation RiskMetrics } \\
\text { committee or the firm does not have a compensation committee, and zero } \\
\text { otherwise. }\end{array}$} \\
\hline Ind director shares & Aggregate percent shareholding of all independent directors. & RiskMetrics \\
\hline Herfindahl sales & Herfindahl index of industry sales based on COMPUSTAT firms & COMPUSTAT \\
\hline Loss & $\begin{array}{l}\text { Dummy variable that equals one if both current and previous earnings } \\
\text { negative. }\end{array}$ & \\
\hline
\end{tabular}




\section{References}

Altman, E.I., 1968, "Financial Ratios, Discriminant Analysis and the Prediction of Corporate Bankruptcy," Journal of Finance 23, 589-609.

Anderson, R.C., S.A. Mansi and D.M. Reeb, 2004, "Board Characteristics, Accounting Report Integrity, and the Cost of Debt," Journal of Accounting \& Economics 37, 315-342.

Armstrong, C.S., J.E. Core and W.R. Guay, 2013, "Do Independent Directors Cause Improvements in Firm Transparency?," University of Pennsylvania Working Paper.

Ashbaugh-Skaife, H., D.W. Collins and R. LaFond, 2006, "The Effects of Corporate Governance on Firms' Credit Ratings," Journal of Accounting \& Economics 42, 203-243.

Asquith, P., R. Gertner and D. Scharfstein, 1994, "Anatomy of Financial Distress: An Examination of Junk-Bond Issuers," Quarterly Journal of Economics 109, 625-658.

Bargeron, L.L., K.M. Lehn and C.J. Zutter, 2010, "Sarbanes-Oxley and Corporate Risk-Taking," Journal of Accounting \& Economics 49, 34-52.

Beltratti, A. and R.M. Stulz, 2012, "The Credit Crisis around the Globe: Why Did Some Banks Perform Better?," Journal of Financial Economics 105, 1-17.

Bertrand, M., E. Duflo and S. Mullainathan, 2004, "How Much Should We Trust Differences-inDifferences Estimates?," Quarterly Journal of Economics 119, 249-275.

Bhojraj, S. and P. Sengupta, 2003, "Effect of Corporate Governance on Bond Ratings and Yields: The Role of Institutional Investors and Outside Directors," Journal of Business 76, 455475.

Bodie, Z. and R.A. Taggart, 1978, "Future Investment Opportunities and Value of Call Provision on a Bond," Journal of Finance 33, 1187-1200.

Boone, A.L., L.C. Field, J.M. Karpoff and C.G. Raheja, 2007, "The Determinants of Corporate Board Size and Composition: An Empirical Analysis," Journal of Financial Economics 85, 66101.

Bradley, M. and D. Chen, 2011, "Corporate Governance and the Cost of Debt: Evidence from Director Limited Liability and Indemnification Provisions," Journal of Corporate Finance 17, 83-107.

Brick, I.E., O. Palmon and J. Wald, 2012, "Too Much Pay-Performance Sensitivity," Review of Economics and Statistics 94, 287-303.

Cain, M.D. and S.B. Mckeon, 2013, "CEO Personal Risk-Taking and Corporate Policies," University of Notre Dame Working Paper.

Chava, S., P. Kumar and A. Warga, 2010, "Managerial Agency and Bond Covenants," Review of Financial Studies 23, 1120-1148.

Chen, D., 2012, "Classified Boards, the Cost of Debt, and Firm Performance," Journal of Banking \& Finance 36, 3346-3365.

Chen, D., 2013, "The Non-Monotonic Effect of Board Independence on Credit Ratings," Journal of Financial Services Research Forthcoming

Chen, D. and Y. Zheng, 2013, "CEO Tenure and Risk-Taking," University of Baltimore Working Paper.

Cheng, S., 2008, "Board Size and the Variability of Corporate Performance," Journal of Financial Economics 87, 157-176.

Chhaochharia, V. and Y. Grinstein, 2007, "Corporate Governance and Firm Value: The Impact of the 2002 Governance Rules," Journal of Finance 62, 1789-1825.

Chhaochharia, V. and Y. Grinstein, 2009, "CEO Compensation and Board Structure," Journal of Finance 64, 231-261. 
Cohen, D.A., A. Dey and T.Z. Lys, 2009, "The Sarbanes Oxley Act of 2002: Implications for Compensation Structure and Managerial Risk-Taking," New York University Working Paper.

Coles, J.L., N.D. Daniel and L. Naveen, 2006, "Managerial Incentives and Risk-Taking," Journal of Financial Economics 79, 431-468.

Core, J.E. and W.R. Guay, 2002, "Estimating the Value of Employee Stock Option Portfolios and Their Sensitivities to Price and Volatility," Journal of Accounting Research 40, 613-630.

Cremers, K.J.M., V.B. Nair and C. Wei, 2007, "Governance Mechanisms and Bond Prices," Review of Financial Studies 20, 1359-1388.

Crump, R.K., V.J. Hotz, G.W. Imbens and O.A. Mitnik, 2009, "Dealing with Limited Overlap in Estimation of Average Treatment Effects," Biometrika 96, 187-199.

DeFond, M., M. Hung, E. Carr and J. Zhang, 2011, "Was the Sarbanes-Oxley Act Good News for Corporate Bondholders?," Accounting Horizons 25, 465-485.

Duchin, R., J.G. Matsusaka and O. Ozbas, 2010, "When Are Outside Directors Effective?," Journal of Financial Economics 96, 195-214.

Ertugrul, M. and S. Hegde, 2008, "Board Compensation Practices and Agency Costs of Debt," Journal of Corporate Finance 14, 512-531.

Fama, E.F., 1980, "Agency Problems and the Theory of the Firm," Journal of Political Economy 88, 288-307.

Fama, E.F. and K.R. French, 2001, "Disappearing Dividends: Changing Firm Characteristics or Low Propensity to Pay?," Journal of Financial Economics 60, 3-43.

Farinha, J., 2003, "Dividend Policy, Corporate Governance and the Managerial Entrenchment Hypothesis: An Empirical Analysis," Journal of Business Finance \& Accounting 30, 1173-1209. Fields, M.A. and P.Y. Keys, 2003, "The Emergence of Corporate Governance from Wall St. To Main St.: Outside Directors, Board Diversity, Earnings Management, and Managerial Incentives to Bear Risk," The Financial Review 38, 1-24.

Gillan, S.L. and L.T. Starks, 2007, "The Evolution of Shareholder Activism in the United States," Journal of Applied Corporate Finance 19, 55-73.

Goh, B.W., J. Ng and K.O. Yong, 2012, "The Effect of Board Independence on the Information Environment and Information Asymmetry," Singapore Management University Working Paper.

Grinstein, Y. and R. Michaely, 2005, "Institutional Holdings and Payout Policy," Journal of Finance 60, 1389-1426.

Grullon, G. and R. Michaely, 2002, "Dividends, Share Repurchases, and the Substitution Hypothesis," Journal of Finance 57, 1649-1684.

Hermalin, B. and M. Weisbach, 2003, "Boards of Directors as an Endogenously Determined Institution, a Survey of the Economic Literature," FRBNY Economic Policy Review April, 7-26.

Hirano, K., G.W. Imbens and G. Ridder, 2003, "Efficient Estimation of Average Treatment Effects Using the Estimated Propensity Score," Econometrica 71, 1161-1189.

$\mathrm{Hu}$, A. and P. Kumar, 2004, "Managerial Entrenchment and Payout Policy," Journal of Financial and Quantitative Analysis 39, 759-790.

Imbens, G.W. and J.M. Wooldridge, 2009, "Recent Developments in the Econometrics of Program Evaluation," Journal of Economic Literature 47, 5-86.

Jensen, M.C. and W.H. Meckling, 1976, "Theory of Firm - Managerial Behavior, Agency Costs and Ownership Structure," Journal of Financial Economics 3, 305-360.

John, T.A. and K. John, 1993, "Top-Management Compensation and Capital Structure," Journal of Finance 48, 949-974. 
Jun, S.-g., M. Jung and R. Walkling, 2009, "Share Repurchase, Executive Options and Wealth Changes to Stockholders and Bondholders," Journal of Corporate Finance 15, 212-229.

Kim, E.H. and Y. Lu, 2012, "Governance in Executive Suites," University of Michigan Working Paper.

Klein, A., 2002, "Economic Determinants of Audit Committee Independence," The Accounting Review 77, 435-452.

Klock, M.S., S.A. Mansi and W.F. Maxwell, 2005, "Does Corporate Governance Matter to Bondholders?," Journal of Financial and Quantitative Analysis 40, 693-719.

Lehn, K., S. Patro and M. Zhao, 2009, "Determinants of the Size and Composition of Us Corporate Boards: 1935-2000," Financial Management 38, 747-780.

Linck, J.S., J.M. Netter and T. Yang, 2008, "The Determinants of Board Structure," Journal of Financial Economics 87, 308-328.

Linck, J.S., J.M. Netter and T. Yang, 2009, "The Effects and Unintended Consequences of the Sarbanes-Oxley Act on the Supply and Demand for Directors," Review of Financial Studies 22, 3287-3328.

Malmendier, U. and G. Tate, 2009, "Superstar Ceos," Quarterly Journal of Economics 124, 1593-1638.

Maxwell, W.F. and C.P. Stephens, 2003, "The Wealth Effects of Repurchases on Bondholders," Journal of Finance 58, 895-919.

Myers, S.C., 1977, "Determinants of Corporate Borrowing," Journal of Financial Economics 5, 147-175.

Ni, Y. and L. Purda, 2012, "Does Monitoring by Independent Directors Reduce Firm Risk?," Shanghai Jiao Tong University Working Paper.

Rosenbaum, P.R. and D.B. Rubin, 1983, "The Central Role of the Propensity Score in Observational Studies for Causal Effects," Biometrika 70, 41-55.

Sengupta, P., 1998, "Corporate Disclosure Quality and the Cost of Debt," The Accounting Review 73, 459-474.

Sharma, V., 2011, "Independent Directors and the Propensity to Pay Dividends," Journal of Corporate Finance 17, 1001-1015.

Shaw, K.W., 2012, "CEO Incentives and the Cost of Debt," Review of Quantitative Finance and Accounting 38, 323-346.

Skinner, D.J., 2008, "The Evolving Relation between Earnings, Dividends, and Stock Repurchases," Journal of Financial Economics 87, 582-609.

Stuart, T. and S. Yim, 2010, "Board Interlocks and the Propensity to Be Targeted in Private Equity Transactions," Journal of Financial Economics 97, 174-189.

White, L.F., 1996, "Executive Compensation and Dividend Policy," Journal of Corporate Finance 2, 335-358.

Wintoki, M.B., 2007, "Corporate Boards and Regulation: The Effect of the Sarbanes-Oxley Act and the Exchange Listing Requirements on Firm Value," Journal of Corporate Finance 13, 229250.

Yim, S., 2013, "The Acquisitiveness of Youth: CEO Age and Acquisition Behavior," Journal of Financial Economics 108, 250-273. 


\section{Table 1. Summary Statistics and Compliance Trend}

This table reports the summary statistics of the variables used in the empirical analysis, the compliance trend, and the comparison between the changes of some key variables of interest of the noncompliant and compliant firms between 2002 and 2005. Panel A reports the summary statistics for the full samples, as well as the sub-samples stratified by the median rating in the cost of debt sample $(\mathrm{BBB}+)$. The full samples include both the bond-level cost of debt sample between 2001 and 2005, and the firm-level risk-taking and payout samples between 1996 and 2005. Panel B reports the time trend of noncompliance. Panel C compares the changes of some key variables of interest over 2002 and 2005 between the noncompliant and compliant firms. Next X stands for the value of X in the following year. \%Per_ind $<0.5$ is the fraction of firms in a given year with less than majority independent boards. $\%$ Ind_audit $=0$ is the fraction of firms in a given year without fully independent audit committees. \%Per_ind $<0.5$ or Ind_audit $=0$ is the fraction of firms in a given year with less than majority independent boards or fully independent audit committees. $\Delta$ stands for the change of a variable between 2002 and 2005 . Ind_audit $=0$ and Per_ind $>=0.5$ at 2002 indicates firms that did not have fully independent audit committees but had majority independent boards at 2002, and increased their board independence after 2002. Num_ind (Num_inside, Num_link) is the number of independent (executive, affiliated) directors on a board. The numbers within the parentheses in Panel C represent the numbers of firms/bonds that the statistics are based on. See the Appendix for the definitions of other variables. The statistics for Bond age, CEO tenure, CEO age, Firm age, and Segment are reported in their raw format without taking logs. Spread, Leverage, Next dividend, Dividend, Next repurchase, Repurchase, ROA, Mb, R\&D, Capexp, CEO shares, Unexercisable options, Exercisable options, and Stock return have been winsorized at the $1^{\text {st }}$ and $99^{\text {th }}$ percentiles. $* * *$, and $* * *$ indicate significance at the $10 \%, 5 \%$, and $1 \%$ levels, respectively.

\begin{tabular}{|c|c|c|c|c|c|c|}
\hline \multicolumn{7}{|c|}{ Panel A: Summary Statistics } \\
\hline \multicolumn{7}{|c|}{ Full Sample } \\
\hline Variable & Observations & P25 & Mean & Median & P75 & Std \\
\hline Spread (\%) & 6252 & 1.02 & 2.46 & 1.53 & 2.59 & 3.64 \\
\hline Per ind & 8283 & 0.57 & 0.68 & 0.71 & 0.82 & 0.18 \\
\hline Ind_audit & 7038 & 1 & 0.76 & 1 & 1 & 0.43 \\
\hline Rate & 6252 & 13 & 15.1 & 15 & 17 & 2.76 \\
\hline Z-score & 3406 & 1.97 & 4.59 & 3.53 & 5.63 & 4.83 \\
\hline Int cov & 6203 & 3.81 & 9.6 & 6.47 & 11.79 & 11.01 \\
\hline Leverage (spread sample) & 6252 & 0.12 & 0.23 & 0.2 & 0.31 & 0.15 \\
\hline Volat & 8328 & -4.04 & -3.74 & -3.76 & -3.44 & 0.44 \\
\hline Next volat & 8329 & -4.06 & -3.77 & -3.79 & -3.48 & 0.44 \\
\hline Dividend & 8329 & 0 & 0.01 & 0.01 & 0.02 & 0.02 \\
\hline Next dividend & 7965 & 0 & 0.01 & 0.01 & 0.02 & 0.02 \\
\hline Repurchase & 7735 & 0 & 0.03 & 0 & 0.03 & 0.05 \\
\hline Next repurchase & 7428 & 0 & 0.03 & 0 & 0.04 & 0.05 \\
\hline Duration (log years) & 6252 & 0.97 & 1.39 & 1.57 & 2 & 0.93 \\
\hline Convexity (log years) & 6252 & 2.15 & 3.09 & 3.36 & 4.23 & 1.74 \\
\hline Bond age (years) & 6252 & 1.84 & 4.9 & 3.94 & 7.27 & 3.87 \\
\hline Size (log \$millions) & 8329 & 6.57 & 7.68 & 7.53 & 8.67 & 1.56 \\
\hline ROA & 8329 & 0.09 & 0.14 & 0.14 & 0.19 & 0.08 \\
\hline $\mathrm{Mb}$ & 8329 & 1.21 & 2.01 & 1.56 & 2.29 & 1.28 \\
\hline Salesgrow & 8329 & 0 & 0.09 & 0.08 & 0.17 & 0.23 \\
\hline Firm age (years) & 8329 & 11.6 & 27.06 & 23.43 & 35.03 & 19.46 \\
\hline Vega $\left(\log \$ 10^{3}\right)$ & 6980 & 3.2 & 3.58 & 4.23 & 5.24 & 3.15 \\
\hline Delta $\left(\log \$ 10^{3}\right)$ & 6796 & 4.65 & 5.66 & 5.67 & 6.7 & 1.71 \\
\hline CEO tenure (years) & 8329 & 2.63 & 7.84 & 5.34 & 10.59 & 7.54 \\
\hline CEO age (years) & 7936 & 51 & 55.71 & 56 & 60 & 7.23 \\
\hline $\mathrm{R} \& \mathrm{D}$ & 8329 & 0 & 0.03 & 0 & 0.03 & 0.05 \\
\hline Capexp & 8329 & 0 & 0.04 & 0.02 & 0.05 & 0.05 \\
\hline Leverage (volatility and dividend sample) & 8329 & 0.04 & 0.16 & 0.13 & 0.25 & 0.14 \\
\hline Cash balance & 8327 & -4.04 & -2.99 & -2.91 & -1.77 & 1.52 \\
\hline Segment & 8213 & 3 & 5.63 & 5 & 7 & 3.27 \\
\hline CEO shares & 8098 & 0 & 0.02 & 0 & 0.01 & 0.05 \\
\hline Unexercisable options & 8327 & 0 & 0 & 0 & 0.01 & 0.01 \\
\hline
\end{tabular}




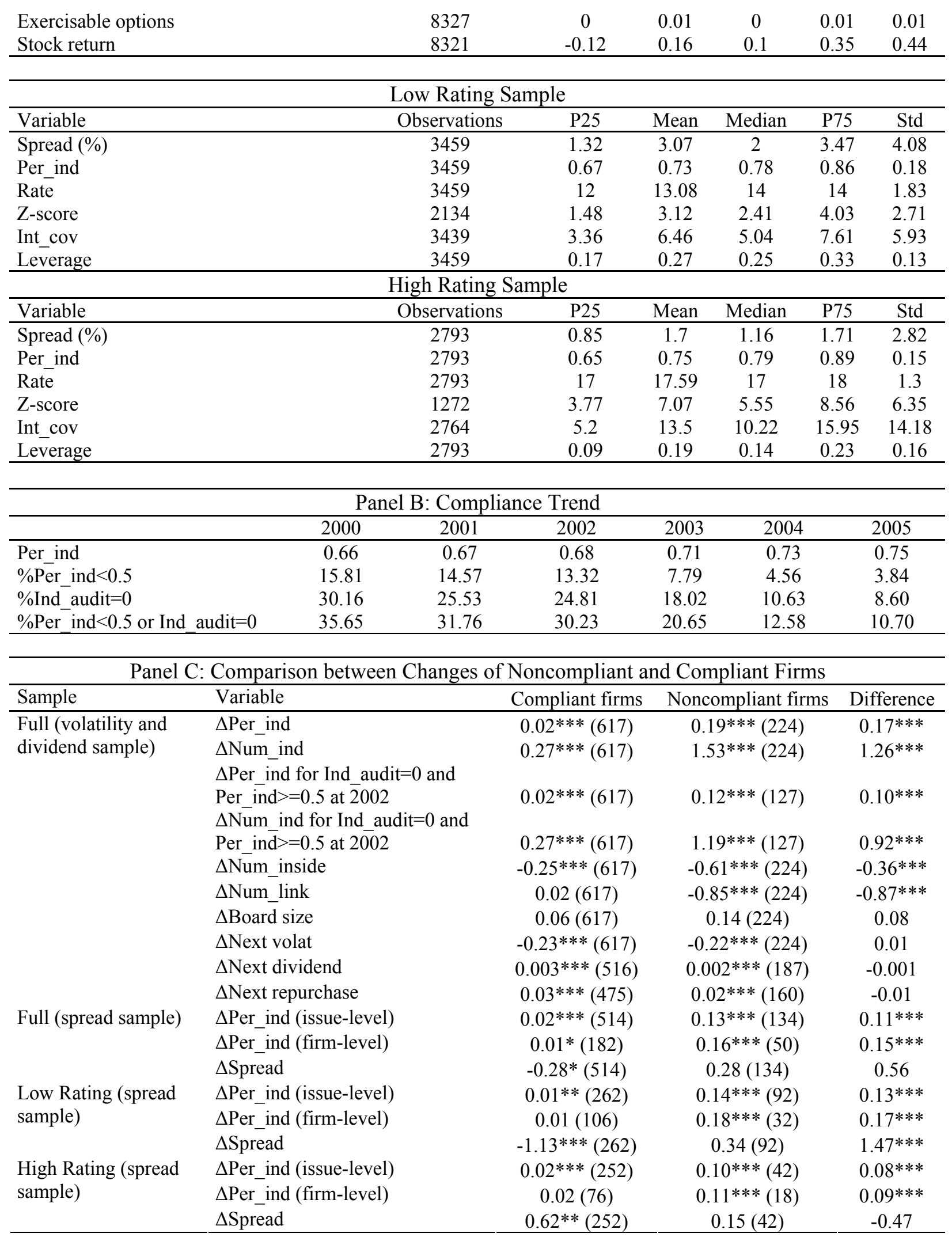




\section{Table 2. Propensity Score Analysis}

This table reports the results on the determinants of the probability of being a noncompliant firm at 2002 (propensity score). Panel A compares the characteristics of the noncompliant and compliant firms that may be relevant to determine noncompliance. Panel B reports the logit regression results predicting the noncompliant status. The sample covers S\&P 1,500 firms at 2002. Lagged X refers to the lagged value of $X$. Lagged size ${ }^{\wedge} 2$ is the square of the lagged firm size. See the Appendix for the definitions of other variables. All models in Panel B also include Fama-French 48-industry dummies and a constant term. Standard errors are adjusted for heteroscedasticity. $t$ statistics are in parentheses. ***, **, and $*$ indicate significance at the $1 \%, 5 \%$, and $10 \%$ levels, respectively.

\begin{tabular}{lccc}
\hline \multicolumn{4}{c}{ Panel A: Comparison between Noncompliant and Compliant Firms at 2002 } \\
\hline Variable & Compliant firms & Noncompliant firms & Difference \\
\hline Lagged size & 7.52 & 7.64 & 0.12 \\
Lagged segment & 1.61 & 1.48 & $-0.13^{* * *}$ \\
Lagged cash flow & 0.61 & 0.52 & -0.09 \\
Lagged mb & 2.05 & 2.05 & 0.00 \\
Lagged salesgrow & 0.02 & 0.04 & 0.02 \\
Lagged R\&D & 0.03 & 0.02 & $-0.01^{* *}$ \\
Lagged CEO shares & 0.02 & 0.04 & $0.02^{* * *}$ \\
Lagged CEO nom & 0.43 & 0.58 & $0.15^{* * *}$ \\
Lagged CEO comp & 0.02 & 0.11 & $0.09^{* * *}$ \\
Lagged ind director shares & 0.016 & 0.024 & $0.008^{* *}$ \\
Lagged ROA & 0.13 & 0.14 & 0.01 \\
\hline
\end{tabular}

\begin{tabular}{|c|c|c|c|c|}
\hline Dependent variable & Noncompliant & Noncompliant & Noncompliant & $\begin{array}{c}\text { (4) } \\
\text { Noncompliant }\end{array}$ \\
\hline Lagged size & $\begin{array}{c}0.194 * * * \\
(2.879)\end{array}$ & $\begin{array}{l}1.024^{* *} \\
(2.260)\end{array}$ & $\begin{array}{l}0.211^{* *} \\
(2.468)\end{array}$ & $\begin{array}{c}0.181 * * * \\
(3.057)\end{array}$ \\
\hline Lagged size $^{\wedge} 2$ & & $\begin{array}{l}-0.052^{*} \\
(-1.839)\end{array}$ & & \\
\hline Lagged segment & $\begin{array}{c}-0.209 \\
(-1.407)\end{array}$ & $\begin{array}{c}-0.197 \\
(-1.322)\end{array}$ & $\begin{array}{l}-0.343^{*} \\
(-1.889)\end{array}$ & \\
\hline Lagged cash flow & $\begin{array}{l}-0.159^{*} \\
(-1.805)\end{array}$ & $\begin{array}{l}-0.161^{*} \\
(-1.843)\end{array}$ & $\begin{array}{l}-0.233^{*} \\
(-1.871)\end{array}$ & \\
\hline Lagged mb & $\begin{array}{l}-0.166^{*} \\
(-1.711)\end{array}$ & $\begin{array}{l}-0.165^{*} \\
(-1.694)\end{array}$ & $\begin{array}{l}-0.220^{*} \\
(-1.737)\end{array}$ & $\begin{array}{l}-0.157 * * \\
(-2.101)\end{array}$ \\
\hline Lagged salesgrow & $\begin{array}{c}0.119 \\
(0.459)\end{array}$ & $\begin{array}{c}0.091 \\
(0.349)\end{array}$ & $\begin{array}{c}0.121 \\
(0.414)\end{array}$ & \\
\hline Lagged R\&D & $\begin{array}{c}-2.778 \\
(-0.913)\end{array}$ & $\begin{array}{c}-2.471 \\
(-0.813)\end{array}$ & $\begin{array}{c}-5.174 \\
(-1.316)\end{array}$ & \\
\hline Lagged CEO shares & $\begin{array}{l}2.853^{* *} \\
(1.969)\end{array}$ & $\begin{array}{l}2.939 * * \\
(2.029)\end{array}$ & $\begin{array}{c}1.951 \\
(1.123)\end{array}$ & $\begin{array}{c}3.042 * * \\
(2.136)\end{array}$ \\
\hline Lagged CEO nom & $\begin{array}{c}0.518 * * * \\
(2.747)\end{array}$ & $\begin{array}{c}0.497 * * * \\
(2.645)\end{array}$ & $\begin{array}{l}0.392^{*} \\
(1.798)\end{array}$ & $\begin{array}{c}0.484 * * * \\
(2.744)\end{array}$ \\
\hline Lagged CEO comp & $\begin{array}{c}1.349 * * * \\
(3.329)\end{array}$ & $\begin{array}{c}1.357 * * * \\
(3.376)\end{array}$ & $\begin{array}{c}1.847 * * * \\
(3.632)\end{array}$ & $\begin{array}{c}1.524 * * * \\
(3.845)\end{array}$ \\
\hline Lagged ind director shares & $\begin{array}{c}5.126^{* * *} \\
(2.814)\end{array}$ & $\begin{array}{c}5.169 * * * \\
(2.799)\end{array}$ & $\begin{array}{c}5.681 * * * \\
(2.674)\end{array}$ & $\begin{array}{l}4.458^{* *} \\
(2.530)\end{array}$ \\
\hline Lagged ROA & $\begin{array}{l}1.171 \\
(0.879)\end{array}$ & $\begin{array}{l}1.014 \\
(0.764)\end{array}$ & $\begin{array}{c}2.973 \\
(1.574)\end{array}$ & \\
\hline Firm age & & & $\begin{array}{c}-0.145 \\
(-0.743)\end{array}$ & \\
\hline Lagged leverage & & & $\begin{array}{c}0.046 \\
(0.049)\end{array}$ & \\
\hline Lagged Herfindahl sales & & & -1.375 & \\
\hline
\end{tabular}


Lagged G-index

Lagged PPE

Lagged volat

CEO tenure

Lagged loss

Observations

Pseudo $\mathrm{R}^{2}$
$(-0.245)$

$-0.029$

$(-0.777)$

$-0.395$

$(-0.551)$

$-0.267$

$(-0.791)$

0.062

(0.585)

0.264

(0.496)

850

0.13
1096

0.10 


\section{Table 3. The Differential Effect of Board Independence on Bond Spreads Conditional on Expected Agency Conflict between Shareholders and Bondholders (Interaction Results)}

This table reports the results using the propensity score weighted DID regressions to examine the differential effects of board independence on the cost of debt conditional on four proxies of the expected agency conflict between shareholders and bondholders, credit rating, Z-score, interest coverage ratio, and leverage. The samples cover senior unsecured bonds of S\&P 1,500 firms from 2001 to 2005. The dependent variable is the yield spread of an outstanding bond in a given year. The weight is one for noncompliant firms and $p /(1-p)$ for compliant firms, where $p$ is the estimated propensity score based on Model 1 of Panel B in Table 2. Post-SOX is a dummy variable that equals one if the year is on or after 2003, and zero otherwise. See the Appendix for the definitions of other variables. All models also include rating dummies, firm fixed effects, and a constant term. Standard errors are adjusted for heteroscedasticity, and clustered at both the bond (same bond across different years) and firm-year (different bonds of the same firm in a given year) levels. $t$-statistics are in parentheses. ${ }^{* *}, * *$, and $*$ indicate significance at the $1 \%$, $5 \%$, and $10 \%$ levels, respectively.

\begin{tabular}{|c|c|c|c|c|c|}
\hline BSCP & (1) & $\begin{array}{c}\text { (2) } \\
\text { Rate }\end{array}$ & $\begin{array}{c}\text { (3) } \\
\text { Z-score }\end{array}$ & $\begin{array}{c}\text { (4) } \\
\text { Int cov }\end{array}$ & $\begin{array}{c}(5) \\
\text { Leverage }\end{array}$ \\
\hline Noncompliant * Post-SOX & $\begin{array}{c}0.131 \\
(0.678)\end{array}$ & $\begin{array}{c}2.831 * * * \\
(2.996)\end{array}$ & $\begin{array}{c}0.967 * * * \\
(2.854)\end{array}$ & $\begin{array}{l}0.598^{*} \\
(1.859)\end{array}$ & $\begin{array}{c}-1.444 * * * \\
(-3.860)\end{array}$ \\
\hline Noncompliant * Post-SOX * BSCP & & $\begin{array}{c}-0.180 * * * \\
(-3.093)\end{array}$ & $\begin{array}{c}-0.210 * * * \\
(-3.744)\end{array}$ & $\begin{array}{c}-0.051 * * \\
(-2.242)\end{array}$ & $\begin{array}{c}6.996 * * * \\
(3.676)\end{array}$ \\
\hline Volat * BSCP & & $\begin{array}{c}-0.175 * * * \\
(-2.611)\end{array}$ & $\begin{array}{c}-0.087 * * \\
(-2.024)\end{array}$ & $\begin{array}{l}-0.032^{*} \\
(-1.927)\end{array}$ & $\begin{array}{c}2.814 \\
(1.611)\end{array}$ \\
\hline Volat & $\begin{array}{c}0.687 * * * \\
(3.097)\end{array}$ & $\begin{array}{c}2.994 * * * \\
(2.681)\end{array}$ & $\begin{array}{c}1.208^{* * *} \\
(4.059)\end{array}$ & $\begin{array}{c}0.909 * * * \\
(3.053)\end{array}$ & $\begin{array}{c}-0.178 \\
(-0.444)\end{array}$ \\
\hline Dividend * BSCP & & $\begin{array}{c}-8.199 * * * \\
(-3.224)\end{array}$ & $\begin{array}{c}-1.609 \\
(-1.012)\end{array}$ & $\begin{array}{c}-0.292 \\
(-0.805)\end{array}$ & $\begin{array}{c}156.554 * * \\
(2.004)\end{array}$ \\
\hline Dividend & $\begin{array}{c}-2.086 \\
(-0.206)\end{array}$ & $\begin{array}{c}116.747 * * * \\
(3.025)\end{array}$ & $\begin{array}{l}13.043 \\
(1.103)\end{array}$ & $\begin{array}{c}1.442 \\
(0.121)\end{array}$ & $\begin{array}{c}-30.590^{* *} \\
(-2.155)\end{array}$ \\
\hline Repurchase * BSCP & & $\begin{array}{c}-0.424 \\
(-0.948)\end{array}$ & $\begin{array}{l}-0.365^{*} \\
(-1.718)\end{array}$ & $\begin{array}{c}-0.001 \\
(-0.009)\end{array}$ & $\begin{array}{c}32.801 * * \\
(2.269)\end{array}$ \\
\hline Repurchase & $\begin{array}{c}-0.161 \\
(-0.145)\end{array}$ & $\begin{array}{c}5.398 \\
(0.767)\end{array}$ & $\begin{array}{c}0.363 \\
(0.190)\end{array}$ & $\begin{array}{c}-0.530 \\
(-0.343)\end{array}$ & $\begin{array}{c}-5.340 * * \\
(-2.321)\end{array}$ \\
\hline Noncompliant * BSCP & & $\begin{array}{c}-0.233 \\
(-1.192)\end{array}$ & $\begin{array}{c}0.240 * * * \\
(3.064)\end{array}$ & $\begin{array}{c}0.047 \\
(1.642)\end{array}$ & $\begin{array}{c}-4.822 * * \\
(-2.095)\end{array}$ \\
\hline Post-SOX * BSCP & & $\begin{array}{c}0.210^{* * *} \\
(3.546)\end{array}$ & $\begin{array}{c}0.002 \\
(0.067)\end{array}$ & $\begin{array}{l}0.029^{*} \\
(1.921)\end{array}$ & $\begin{array}{c}-3.045^{* *} \\
(-2.236)\end{array}$ \\
\hline Post-SOX & $\begin{array}{c}-0.280 \\
(-1.610)\end{array}$ & $\begin{array}{c}-3.774 * * * \\
(-3.942)\end{array}$ & $\begin{array}{c}-0.201 \\
(-0.821)\end{array}$ & $\begin{array}{c}-0.599 * * \\
(-2.382)\end{array}$ & $\begin{array}{c}0.239 \\
(0.839)\end{array}$ \\
\hline Duration * BSCP & & $\begin{array}{c}0.235 \\
(0.648)\end{array}$ & $\begin{array}{c}-0.256 \\
(-1.441)\end{array}$ & $\begin{array}{c}0.051 \\
(0.873)\end{array}$ & $\begin{array}{l}-8.412 * \\
(-1.764)\end{array}$ \\
\hline Duration & $\begin{array}{c}-16.968 * * * \\
(-18.169)\end{array}$ & $\begin{array}{c}-20.422 * * * \\
(-3.418)\end{array}$ & $\begin{array}{c}-15.068 * * * \\
(-8.990)\end{array}$ & $\begin{array}{c}-17.545 * * * \\
(-14.424)\end{array}$ & $\begin{array}{c}-14.433 * * * \\
(-9.992)\end{array}$ \\
\hline Convexity * BSCP & & $\begin{array}{c}-0.054 \\
(-0.313)\end{array}$ & $\begin{array}{c}0.138 \\
(1.520)\end{array}$ & $\begin{array}{c}-0.019 \\
(-0.645)\end{array}$ & $\begin{array}{c}3.624 \\
(1.596)\end{array}$ \\
\hline Convexity & $\begin{array}{c}8.209 * * * \\
(17.945)\end{array}$ & $\begin{array}{c}8.953 * * * \\
(3.180)\end{array}$ & $\begin{array}{c}7.299 * * * \\
(8.558)\end{array}$ & $\begin{array}{l}8.439 * * * \\
(14.309)\end{array}$ & $\begin{array}{c}7.074 * * * \\
(9.873)\end{array}$ \\
\hline Bond age * BSCP & & $\begin{array}{c}0.011 \\
(0.453)\end{array}$ & $\begin{array}{c}-0.016 \\
(-1.577)\end{array}$ & $\begin{array}{c}0.002 \\
(0.499)\end{array}$ & $\begin{array}{c}-0.223 \\
(-0.396)\end{array}$ \\
\hline Bond age & $\begin{array}{l}-0.090^{*} \\
(-1.748)\end{array}$ & $\begin{array}{c}-0.271 \\
(-0.656)\end{array}$ & $\begin{array}{c}0.050 \\
(0.680)\end{array}$ & $\begin{array}{c}-0.108 \\
(-1.380)\end{array}$ & $\begin{array}{c}-0.026 \\
(-0.245)\end{array}$ \\
\hline Leverage * BSCP & & $\begin{array}{c}-0.388 \\
(-0.664)\end{array}$ & $\begin{array}{c}-0.211 \\
(-0.267)\end{array}$ & $\begin{array}{c}-0.150 \\
(-1.118)\end{array}$ & $\begin{array}{c}-1.407 \\
(-0.218)\end{array}$ \\
\hline Leverage & $\begin{array}{c}-1.836 \\
(-1.036)\end{array}$ & $\begin{array}{c}2.584 \\
(0.317)\end{array}$ & $\begin{array}{c}3.868 * * \\
(1.979)\end{array}$ & $\begin{array}{c}-1.658 \\
(-0.889)\end{array}$ & $\begin{array}{c}20.291^{*} \\
(1.793)\end{array}$ \\
\hline
\end{tabular}




\begin{tabular}{lccccc} 
Size * BSCP & & 0.094 & $0.095^{* * *}$ & $0.022^{* * *}$ & $-2.992^{* * *}$ \\
Size & & $(1.329)$ & $(3.157)$ & $(2.971)$ & $(-3.017)$ \\
& $-2.313^{* * *}$ & $-3.199^{* * *}$ & $-1.586^{* * *}$ & $-2.390^{* * *}$ & $-1.111^{* * *}$ \\
ROA* BSCP & $(-5.733)$ & $(-3.016)$ & $(-4.238)$ & $(-5.707)$ & $(-2.929)$ \\
& & $2.346^{* * *}$ & $0.637 * *$ & 0.060 & -13.837 \\
ROA & & $(3.177)$ & $(2.015)$ & $(0.714)$ & $(-0.666)$ \\
& 1.044 & $-32.680^{* * *}$ & -2.038 & 3.068 & 3.640 \\
Mb* BSCP & $(0.519)$ & $(-2.887)$ & $(-0.701)$ & $(1.123)$ & $(1.099)$ \\
& & -0.045 & -0.017 & -0.010 & 1.026 \\
Mb & & $-0.979)$ & $(-0.825)$ & $(-1.515)$ & $(0.406)$ \\
& $0.711^{* * *}$ & $1.390^{*}$ & $0.583 * *$ & $0.856^{* * *}$ & $0.362^{*}$ \\
Salesgrow * BSCP & $(3.955)$ & $(1.672)$ & $(2.121)$ & $(3.004)$ & $(1.920)$ \\
& & -0.055 & $-0.065 *$ & -0.024 & $8.373^{* * *}$ \\
Salesgrow & & $-0.627)$ & $(-1.669)$ & $(-1.471)$ & $(4.016)$ \\
& $0.396^{*}$ & 1.234 & -0.160 & $0.772 * * *$ & $-1.618^{* * *}$ \\
Firm age * BSCP & $(1.792)$ & $(0.993)$ & $(-0.605)$ & $(2.655)$ & $(-3.448)$ \\
& & $-0.595 * *$ & 0.004 & 0.000 & $6.222^{* * *}$ \\
Firm age & & $(-2.641)$ & $(0.069)$ & $(0.005)$ & $(3.017)$ \\
& $1.972 * *$ & $10.240^{* * *}$ & $1.457 *$ & $2.083 * *$ & 0.288 \\
Observations & $(2.450)$ & $(2.986)$ & $(1.813)$ & $(2.545)$ & $(0.342)$ \\
Adjusted R ${ }^{2}$ & 6252 & 6252 & 3406 & 6203 & 6252 \\
& 0.47 & 0.52 & 0.53 & 0.48 & 0.50 \\
\hline
\end{tabular}




\section{Table 4. The Differential Effect of Board Independence on Bond Spreads Conditional on Expected Agency Conflict \\ between Shareholders and Bondholders (Sub-Sample Results)}

This table reports the results using the propensity score weighted DID regressions to examine the differential effects of board independence on the cost of debt conditional on sub-samples characterized by different expected agency conflict between shareholders and bondholders, as proxied by credit rating, Z-score, interest coverage ratio, and leverage, respectively. The samples cover senior unsecured bonds of S\&P 1,500 firms from 2001 to 2005. Low (High) Rating (Zscore, Interest coverage ratio, Leverage) is the sub-sample with ratings (Z-scores, interest coverage ratios, leverages) at or below (above) the median value in the sample. The dependent variable is the yield spread of an outstanding bond in a given year. The weight is one for noncompliant firms and $p /(1-p)$ for compliant firms, where $p$ is the estimated propensity score based on Model 1 of Panel B in Table 2. Post-SOX is a dummy variable that equals one if the year is on or after 2003, and zero otherwise. See the Appendix for the definitions of other variables. All models also include rating dummies, firm fixed effects, and a constant term. Standard errors are adjusted for heteroscedasticity, and clustered at both the bond and firm-year levels. $t$-statistics are in parentheses. ${ }^{* * *},{ }^{* *}$, and ${ }^{*}$ indicate significance at the $1 \%, 5 \%$, and $10 \%$ levels, respectively.

\begin{tabular}{|c|c|c|c|c|c|c|c|c|}
\hline Sample & $\begin{array}{c}\text { (1) } \\
\text { Low Rating }\end{array}$ & $\begin{array}{c}\text { (2) } \\
\text { High Rating }\end{array}$ & $\begin{array}{c}(3) \\
\text { Low Z-score }\end{array}$ & $\begin{array}{c}(4) \\
\text { High Z-score }\end{array}$ & $\begin{array}{c}5) \\
\text { Low Interest } \\
\text { coverage ratio }\end{array}$ & $\begin{array}{c}(6) \\
\text { High Interest } \\
\text { coverage ratio }\end{array}$ & $\begin{array}{c}(7) \\
\text { Low } \\
\text { Leverage } \\
\end{array}$ & $\begin{array}{c}(8) \\
\text { High } \\
\text { Leverage } \\
\end{array}$ \\
\hline Noncompliant * Post-SOX & $\begin{array}{c}0.803 * * * \\
(2.668)\end{array}$ & $\begin{array}{l}-0.281 * \\
(-1.830)\end{array}$ & $\begin{array}{l}0.639 * \\
(1.754)\end{array}$ & $\begin{array}{l}-0.309 * \\
(-1.647)\end{array}$ & $\begin{array}{c}0.509 \\
(1.561)\end{array}$ & $\begin{array}{c}-0.226 \\
(-1.507)\end{array}$ & $\begin{array}{c}-0.404 * * \\
(-2.262)\end{array}$ & $\begin{array}{c}0.732 * * \\
(2.140)\end{array}$ \\
\hline Post-SOX & $\begin{array}{c}-0.887 * * * \\
(-3.237)\end{array}$ & $\begin{array}{c}-0.097 \\
(-0.699)\end{array}$ & $\begin{array}{c}-0.588 * * \\
(-1.996)\end{array}$ & $\begin{array}{l}-0.309^{*} \\
(-1.760)\end{array}$ & $\begin{array}{c}-0.596 * * \\
(-2.059)\end{array}$ & $\begin{array}{l}-0.273^{*} \\
(-1.874)\end{array}$ & $\begin{array}{c}-0.007 \\
(-0.046)\end{array}$ & $\begin{array}{c}-0.814 * * * \\
(-2.580)\end{array}$ \\
\hline Volat & $\begin{array}{c}1.107 * * * \\
(3.444)\end{array}$ & $\begin{array}{c}0.211 \\
(1.107)\end{array}$ & $\begin{array}{l}0.831 * * \\
(2.281)\end{array}$ & $\begin{array}{c}0.081 \\
(0.324)\end{array}$ & $\begin{array}{c}0.884 * * \\
(2.399)\end{array}$ & $\begin{array}{c}0.100 \\
(0.637)\end{array}$ & $\begin{array}{c}0.458 * * \\
(2.373)\end{array}$ & $\begin{array}{c}1.022 * * * \\
(2.750)\end{array}$ \\
\hline Dividend & $\begin{array}{l}15.174 \\
(1.157)\end{array}$ & $\begin{array}{c}-16.812 * * \\
(-2.162)\end{array}$ & $\begin{array}{l}16.013 \\
(1.242)\end{array}$ & $\begin{array}{l}-16.007 \\
(-1.200)\end{array}$ & $\begin{array}{c}35.812 * * \\
(2.050)\end{array}$ & $\begin{array}{c}-26.496 * * \\
(-2.314)\end{array}$ & $\begin{array}{c}-17.932 * \\
(-1.693)\end{array}$ & $\begin{array}{l}25.238 \\
(1.448)\end{array}$ \\
\hline Repurchase & $\begin{array}{c}-2.313 \\
(-1.295)\end{array}$ & $\begin{array}{c}-0.318 \\
(-0.318)\end{array}$ & $\begin{array}{l}-8.029^{*} \\
(-1.920)\end{array}$ & $\begin{array}{c}-2.012 \\
(-1.558)\end{array}$ & $\begin{array}{c}-2.526 \\
(-0.629)\end{array}$ & $\begin{array}{c}-0.572 \\
(-0.743)\end{array}$ & $\begin{array}{c}-0.626 \\
(-0.667)\end{array}$ & $\begin{array}{l}-3.673 \\
(-1.157)\end{array}$ \\
\hline Duration & $\begin{array}{c}-17.492 * * * \\
(-11.508)\end{array}$ & $\begin{array}{c}-16.487 * * * \\
(-16.164)\end{array}$ & $\begin{array}{c}-15.943 * * * \\
(-8.617)\end{array}$ & $\begin{array}{c}-16.867 * * * \\
(-14.764)\end{array}$ & $\begin{array}{c}-17.995 * * * \\
(-12.219)\end{array}$ & $\begin{array}{c}-15.753 * * * \\
(-15.750)\end{array}$ & $\begin{array}{c}-15.505 * * * \\
(-15.366)\end{array}$ & $\begin{array}{c}-18.072 * * * \\
(-12.551)\end{array}$ \\
\hline Convexity & $\begin{array}{l}8.350 * * * \\
(11.334)\end{array}$ & $\begin{array}{c}8.118 * * * \\
(15.596)\end{array}$ & $\begin{array}{c}7.775 * * * \\
(8.318)\end{array}$ & $\begin{array}{l}8.253 * * * \\
(14.299)\end{array}$ & $\begin{array}{l}8.697 * * * \\
(12.205)\end{array}$ & $\begin{array}{l}7.623 * * * \\
(15.202)\end{array}$ & $\begin{array}{l}7.492 * * * \\
(14.811)\end{array}$ & $\begin{array}{l}8.757 * * * \\
(12.527)\end{array}$ \\
\hline Bond age & $\begin{array}{c}-0.089 \\
(-1.040)\end{array}$ & $\begin{array}{c}-0.092 * * \\
(-2.474)\end{array}$ & $\begin{array}{c}-0.024 \\
(-0.359)\end{array}$ & $\begin{array}{c}-0.025 \\
(-0.614)\end{array}$ & $\begin{array}{l}-0.154 * \\
(-1.835)\end{array}$ & $\begin{array}{l}-0.044 \\
(-1.116)\end{array}$ & $\begin{array}{c}-0.018 \\
(-0.489)\end{array}$ & $\begin{array}{l}-0.160 * \\
(-1.953)\end{array}$ \\
\hline Leverage & $\begin{array}{c}-5.532 * * \\
(-2.528)\end{array}$ & $\begin{array}{c}4.128 * * * \\
(2.611)\end{array}$ & $\begin{array}{c}2.667 \\
(0.976)\end{array}$ & $\begin{array}{l}3.286^{*} \\
(1.774)\end{array}$ & $\begin{array}{c}-5.568 * * \\
(-2.245)\end{array}$ & $\begin{array}{c}1.637 \\
(1.051)\end{array}$ & $\begin{array}{c}-1.922 \\
(-0.868)\end{array}$ & $\begin{array}{l}-3.096 \\
(-1.227)\end{array}$ \\
\hline Size & $\begin{array}{c}-3.273 * * * \\
(-6.225)\end{array}$ & $\begin{array}{l}-0.000 \\
(-0.002)\end{array}$ & $\begin{array}{c}-2.233 * * * \\
(-3.971)\end{array}$ & $\begin{array}{c}-0.197 \\
(-0.752)\end{array}$ & $\begin{array}{c}-3.690 * * * \\
(-6.325)\end{array}$ & $\begin{array}{c}-0.275 \\
(-1.348)\end{array}$ & $\begin{array}{c}-0.814 * * \\
(-2.353)\end{array}$ & $\begin{array}{c}-3.479 * * * \\
(-5.494)\end{array}$ \\
\hline ROA & $\begin{array}{c}1.027 \\
(0.383)\end{array}$ & $\begin{array}{c}1.822 \\
(1.111)\end{array}$ & $\begin{array}{c}-3.837 \\
(-0.837)\end{array}$ & $\begin{array}{c}2.118 \\
(1.282)\end{array}$ & $\begin{array}{c}-2.820 \\
(-0.580)\end{array}$ & $\begin{array}{c}0.565 \\
(0.430)\end{array}$ & $\begin{array}{c}-1.149 \\
(-0.725)\end{array}$ & $\begin{array}{c}0.432 \\
(0.098)\end{array}$ \\
\hline $\mathrm{Mb}$ & $1.764 * * *$ & $0.204 * *$ & 0.892 & 0.141 & 0.568 & 0.139 & $0.325 * * *$ & 0.852 \\
\hline
\end{tabular}




\begin{tabular}{|c|c|c|c|c|c|c|c|c|}
\hline & $(2.930)$ & $(1.985)$ & $(1.035)$ & $(1.207)$ & $(0.640)$ & (1.599) & $(2.661)$ & $(0.728)$ \\
\hline \multirow[t]{2}{*}{ Salesgrow } & 0.386 & 0.071 & 0.289 & $-0.725 * *$ & $1.141 * * *$ & $-0.419 *$ & $-0.640^{*}$ & $0.883 * * *$ \\
\hline & $(1.357)$ & $(0.272)$ & $(1.118)$ & $(-2.469)$ & $(3.420)$ & $(-1.659)$ & $(-1.896)$ & (2.844) \\
\hline \multirow[t]{2}{*}{ Firm age } & $3.182 * *$ & -0.432 & $4.167 * * *$ & -1.141 & $3.599^{*}$ & $-0.932 *$ & -0.586 & $6.003 * * *$ \\
\hline & $(2.452)$ & $(-0.673)$ & $(2.620)$ & $(-1.219)$ & (1.769) & $(-1.862)$ & $(-0.812)$ & $(2.657)$ \\
\hline Observations & 3459 & 2793 & 1705 & 1701 & 3114 & 3089 & 3127 & 3125 \\
\hline Adjusted $\mathrm{R}^{2}$ & 0.45 & 0.56 & 0.44 & 0.66 & 0.43 & 0.58 & 0.56 & 0.43 \\
\hline
\end{tabular}




\section{Table 5. The Effect of Board Independence on Firm Risk and Payout Policy}

This table reports the results using the propensity score weighted difference-in-differences (DID) regressions to examine the effects of board independence on firm risk and payout policy. The sample covers S\&P 1,500 firms from 1996 to 2005 . The weight is one for noncompliant firms and $p /(1-p)$ for compliant firms, where $p$ is the estimated probability of being a noncompliant firm at 2002 (propensity score) based on Model 1 of Panel B in Table 2. PostSOX is a dummy variable that equals one if the year is on or after 2003, and zero otherwise. Next X stands for the value of $\mathrm{X}$ in the following year. See the Appendix for the definitions of other variables. All models also include firm fixed effects and a constant term. Standard errors are adjusted for heteroscedasticity and clustered at the firm level. $t$-statistics are in parentheses. $* * *, * *$, and * indicate significance at the $1 \%, 5 \%$, and $10 \%$ levels, respectively.

(1) (2) (3)

\begin{tabular}{|c|c|c|c|}
\hline Dependent variable & Next volat & Next dividend & Next repurcha \\
\hline \multirow{2}{*}{ Noncompliant * Post-SOX } & $0.039^{* *}$ & -0.000 & 0.002 \\
\hline & $(2.117)$ & $(-0.226)$ & $(0.587)$ \\
\hline \multirow[t]{2}{*}{ Post-SOX } & $-0.244 * * *$ & $0.001 * *$ & 0.003 \\
\hline & $(-14.639)$ & (2.087) & $(1.451)$ \\
\hline \multirow{2}{*}{ Vega } & -0.002 & & \\
\hline & $(-0.773)$ & & \\
\hline \multirow[t]{2}{*}{ Delta } & 0.008 & & \\
\hline & $(1.591)$ & & \\
\hline \multirow[t]{2}{*}{ CEO tenure } & 0.001 & 0.000 & 0.001 \\
\hline & $(0.135)$ & $(1.611)$ & $(0.646)$ \\
\hline \multirow[t]{2}{*}{ CEO age } & 0.048 & & \\
\hline & $(0.714)$ & & \\
\hline \multirow[t]{2}{*}{ Size } & -0.009 & -0.000 & $0.006^{* *}$ \\
\hline & $(-0.549)$ & $(-0.223)$ & $(2.296)$ \\
\hline \multirow{2}{*}{ ROA } & $-0.308 * * *$ & $0.013^{* *}$ & $0.102 * * *$ \\
\hline & $(-2.708)$ & (2.568) & $(4.274)$ \\
\hline \multirow[t]{2}{*}{$\mathrm{Mb}$} & $0.068 * * *$ & 0.000 & -0.001 \\
\hline & $(7.873)$ & $(0.178)$ & $(-0.403)$ \\
\hline \multirow[t]{2}{*}{ Salesgrow } & $0.112 * * *$ & $-0.002 * * *$ & $-0.012 * * *$ \\
\hline & $(4.806)$ & $(-2.895)$ & $(-3.019)$ \\
\hline \multirow[t]{2}{*}{ Firm age } & $-0.170 * * *$ & 0.002 & 0.006 \\
\hline & $(-5.203)$ & (1.031) & $(0.975)$ \\
\hline \multirow[t]{2}{*}{$\mathrm{R} \& \mathrm{D}$} & $0.683 * *$ & & \\
\hline & (2.138) & & \\
\hline \multirow[t]{2}{*}{ Capexp } & 0.016 & & \\
\hline & $(0.119)$ & & \\
\hline \multirow{2}{*}{ Leverage } & $0.149 *$ & $-0.018 * * *$ & $-0.062 * * *$ \\
\hline & $(1.782)$ & $(-4.520)$ & $(-4.294)$ \\
\hline \multirow[t]{2}{*}{ Cash balance } & $-0.018 * * *$ & 0.000 & $0.004 * * *$ \\
\hline & $(-3.065)$ & (1.014) & (3.683) \\
\hline \multirow[t]{2}{*}{ Segment } & 0.019 & & \\
\hline & (1.266) & & \\
\hline \multirow[t]{2}{*}{ Volat } & $0.346 * * *$ & & \\
\hline & (16.368) & & \\
\hline \multirow{2}{*}{ CEO shares } & & $-0.017 * *$ & -0.033 \\
\hline & & $(-2.131)$ & $(-0.975)$ \\
\hline \multirow[t]{2}{*}{ Unexercisable options } & & $-0.114^{*}$ & -0.278 \\
\hline & & $(-1.748)$ & $(-1.261)$ \\
\hline \multirow[t]{2}{*}{ Exercisable options } & & -0.037 & $-0.472 * * *$ \\
\hline & & $(-0.927)$ & $(-2.604)$ \\
\hline \multirow[t]{2}{*}{ Stock return } & & -0.000 & -0.001 \\
\hline & & $(-1.365)$ & $(-0.593)$ \\
\hline Observations & 6455 & 7733 & 7223 \\
\hline
\end{tabular}


Adjusted $\mathrm{R}^{2}$ 


\section{Table 6. Robustness Check by Propensity Score Matching}

This table reports the results using the propensity score matched DID regressions to check the robustness of the results with respect to the differential effects of board independence on the cost of debt conditional on credit ratings. Results using three matching methods are presented: one-to-one matching without replacement (One-to-one), nearest neighbor matching with five compliant firms (if available) matched with each noncompliant firm (Nearest five neighbors), and kernel matching (Kernel). The samples cover senior unsecured bonds of S\&P 1,500 firms from 2001 to 2005 . The dependent variable is the yield spread of an outstanding bond in a given year. The weight is one for noncompliant firms and $p /(1-p)$ for compliant firms, where $p$ is the estimated propensity score based on Model 1 of Panel B in Table 2. Post-SOX is a dummy variable that equals one if the year is on or after 2003, and zero otherwise. See the Appendix for the definitions of other variables. All models also include the control variables as in Model 2 of Table 3, rating dummies, firm fixed effects, and a constant term. Standard errors are adjusted for heteroscedasticity, and clustered at both the bond and firm-year levels. $t$-statistics are in parentheses. ${ }^{* * *}, * *$, and * indicate significance at the $1 \%, 5 \%$, and $10 \%$ levels, respectively.

\begin{tabular}{lccc}
\hline & $(1)$ & $(2)$ & $(3)$ \\
Matching method & One-to-one & Nearest five neighbors & Kernel \\
\hline \multirow{2}{*}{ Noncompliant * Post-SOX * Rate } & $-0.232^{* *}$ & $-0.230^{* * *}$ & $-0.211^{* * *}$ \\
& $(-2.451)$ & $(-3.149)$ & $(-3.381)$ \\
Noncompliant * Post-SOX & $3.551^{* *}$ & $3.582^{* * *}$ & $3.321^{* * *}$ \\
& $(2.375)$ & $(3.089)$ & $(3.344)$ \\
Volat* Rate & -0.157 & $-0.273^{* * *}$ & $-0.190^{* *}$ \\
& $(-1.448)$ & $(-2.858)$ & $(-2.394)$ \\
Volat & 2.793 & $4.604^{* * *}$ & $3.270^{* *}$ \\
& $(1.568)$ & $(2.917)$ & $(2.540)$ \\
Dividend * Rate & -3.908 & -5.615 & $-8.107^{* * *}$ \\
& $(-1.125)$ & $(-1.505)$ & $(-3.219)$ \\
Dividend & 50.691 & 86.060 & $121.881^{* * *}$ \\
& $(0.946)$ & $(1.413)$ & $(3.166)$ \\
Repurchase * Rate & -0.336 & -0.523 & -0.437 \\
& $(-0.512)$ & $(-0.928)$ & $(-0.972)$ \\
Repurchase & 4.978 & 5.900 & 5.382 \\
& $(0.485)$ & $(0.692)$ & $(0.766)$ \\
Observations & 2366 & 4061 & 5992 \\
Adjusted R & 0.52 & 0.53 & 0.51 \\
\hline
\end{tabular}




\section{Table 7. The Effect of Board Independence on Risk-Taking Policies}

This table reports the results using the propensity score weighted DID regressions to examine the effects of board independence on risk-taking corporate policies. The sample covers S\&P 1,500 firms from 1996 to 2005. The weight is one for noncompliant firms and $p /(1-p)$ for compliant firms, where $p$ is the estimated propensity score based on Model 1 of Panel B in Table 2. Next X stands for the value of X in the following year. Post-SOX is a dummy variable that equals one if the year is on or after 2003, and zero otherwise. See the Appendix for the definitions of other variables. All models also include firm fixed effects and a constant term. Standard errors are adjusted for heteroscedasticity and clustered at the firm level. $t$-statistics are in parentheses. $* * *, * *$, and $*$ indicate significance

at the $1 \%, 5 \%$, and $10 \%$ levels, respectively.

\begin{tabular}{|c|c|c|c|c|}
\hline Dependent variable & Next R\&D & Next Leverage & Next Leverage & Next Cash balance \\
\hline \multirow[t]{2}{*}{ Noncompliant * Post-SOX } & 0.001 & 0.010 & $0.013^{* *}$ & $-0.140^{*}$ \\
\hline & $(0.996)$ & (1.451) & $(2.155)$ & $(-1.773)$ \\
\hline \multirow[t]{2}{*}{ Post-SOX } & 0.001 & $-0.032 * * *$ & $-0.031^{* * *}$ & $0.337 * * *$ \\
\hline & $(0.963)$ & $(-6.041)$ & $(-8.207)$ & $(5.358)$ \\
\hline \multirow[t]{2}{*}{ Vega } & 0.000 & 0.000 & & $0.022 * *$ \\
\hline & $(0.137)$ & $(0.413)$ & & $(2.045)$ \\
\hline \multirow{2}{*}{ Delta } & 0.000 & 0.001 & & -0.023 \\
\hline & $(0.567)$ & $(0.463)$ & & $(-1.059)$ \\
\hline \multirow[t]{2}{*}{ CEO tenure } & 0.000 & -0.002 & & -0.028 \\
\hline & $(0.155)$ & $(-0.669)$ & & $(-0.886)$ \\
\hline \multirow[t]{2}{*}{ CEO age } & -0.003 & -0.020 & & 0.239 \\
\hline & $(-0.697)$ & $(-0.779)$ & & $(0.859)$ \\
\hline \multirow[t]{2}{*}{ Size } & $-0.002 * *$ & -0.008 & & $-0.125^{* *}$ \\
\hline & $(-1.965)$ & $(-1.281)$ & & $(-2.198)$ \\
\hline \multirow{2}{*}{ ROA } & $0.023 * *$ & $-0.172 * * *$ & $-0.195 * * *$ & -0.740 \\
\hline & $(2.230)$ & $(-4.281)$ & $(-5.525)$ & $(-1.505)$ \\
\hline \multirow[t]{2}{*}{$\mathrm{Mb}$} & -0.001 & $-0.010 * * *$ & $-0.012 * * *$ & $0.082^{* *}$ \\
\hline & $(-0.979)$ & $(-4.200)$ & $(-7.005)$ & (2.408) \\
\hline \multirow[t]{2}{*}{ Salesgrow } & $-0.004 * *$ & $0.026^{* * *}$ & $0.019 * * *$ & $-0.252 * * *$ \\
\hline & $(-2.476)$ & $(2.685)$ & $(2.836)$ & $(-2.892)$ \\
\hline \multirow[t]{2}{*}{ Firm age } & -0.001 & 0.018 & & $0.370 * *$ \\
\hline & $(-0.530)$ & $(1.323)$ & & $(2.556)$ \\
\hline \multirow[t]{2}{*}{ PPE } & & -0.006 & & \\
\hline & & $(-0.143)$ & & \\
\hline Observations & 6278 & 6242 & 8493 & 6276 \\
\hline Adjusted $\mathrm{R}^{2}$ & 0.92 & 0.84 & 0.83 & 0.77 \\
\hline
\end{tabular}

